\title{
Theoretical constraints of physical and chemical properties of hydrothermal fluids on variations in chemolithotrophic microbial communities in seafloor hydrothermal systems
}

Kentaro Nakamura ${ }^{1,2^{*}}$ and Ken Takai ${ }^{1,3}$

\begin{abstract}
In the past few decades, chemosynthetic ecosystems at deep-sea hydrothermal vents have received attention as plausible analogues to the early ecosystems of Earth, as well as to extraterrestrial ecosystems. These ecosystems are sustained by chemical energy obtained from inorganic redox substances (e.g., $\mathrm{H}_{2} \mathrm{~S}, \mathrm{CO}_{2}, \mathrm{H}_{2}, \mathrm{CH}_{4}$, and $\mathrm{O}_{2}$ ) in hydrothermal fluids and ambient seawater. The chemical and isotope compositions of the hydrothermal fluid are, in turn, controlled by subseafloor physical and chemical processes, including fluid-rock interactions, phase separation and partitioning of fluids, and precipitation of minerals. We hypothesized that specific physicochemical principles describe the linkages among the living ecosystems, hydrothermal fluids, and geological background in deep-sea hydrothermal systems. We estimated the metabolic energy potentially available for productivity by chemolithotrophic microorganisms at various hydrothermal vent fields. We used a geochemical model based on hydrothermal fluid chemistry data compiled from 89 globally distributed hydrothermal vent sites. The model estimates were compared to the observed variability in extant microbial communities in seafloor hydrothermal environments. Our calculations clearly show that representative chemolithotrophic metabolisms (e.g., thiotrophic, hydrogenotrophic, and methanotrophic) respond differently to geological and geochemical variations in the hydrothermal systems. Nearly all of the deep-sea hydrothermal systems provide abundant energy for organisms with aerobic thiotrophic metabolisms; observed variations in the $\mathrm{H}_{2} \mathrm{~S}$ concentrations among the hydrothermal fluids had little effect on the energetics of thiotrophic metabolism. Thus, these organisms form the base of the chemosynthetic microbial community in global deep-sea hydrothermal environments. In contrast, variations in $\mathrm{H}_{2}$ concentrations in hydrothermal fluids significantly impact organisms with aerobic and anaerobic hydrogenotrophic metabolisms. Particularly in $\mathrm{H}_{2}$-rich ultramafic rock-hosted hydrothermal systems, anaerobic and aerobic hydrogenotrophy is more energetically significant than thiotrophy. The $\mathrm{CH}_{4}$ concentration also has a considerable impact on organisms with aerobic and anaerobic methanotrophic metabolisms, particularly in sediment-associated hydrothermal systems. Recently clarified patterns and functions of existing microbial communities and their metabolisms are generally consistent with the results of our thermodynamic modeling of the hydrothermal mixing zones. These relationships provide important directions for future research addressing the origin and early evolution of life on Earth as well as for the search for extraterrestrial life.
\end{abstract}

Keywords: Deep-sea hydrothermal systems; Chemosynthetic ecosystems; Hydrothermal fluid chemistry; Host rock geochemistry; Geochemical modeling; Bioavailable energy yield

\footnotetext{
* Correspondence: kentaron@sys.t.u-tokyo.ac.jp

${ }^{1}$ Precambrian Ecosystem Laboratory (PEL), Japan Agency for Marine-Earth

Science and Technology (JAMSTEC), 2-15 Natsushima-cho, Yokosuka,

Kanagawa 237-0061, Japan

${ }^{2}$ Current address: Department of Systems Innovation, School of Engineering,

The University of Tokyo, 7-3-1 Hongo, Bunkyo-ku, Tokyo 113-8656, Japan

Full list of author information is available at the end of the article
}

\section{实 Springer}

(c) 2014 Nakamura and Takai; licensee Springer. This is an Open Access article distributed under the terms of the Creative Commons Attribution License (http://creativecommons.org/licenses/by/2.0), which permits unrestricted use, distribution, and reproduction in any medium, provided the original work is properly credited. 


\section{Review Introduction}

Deep-sea hydrothermal vents host some of the most diverse microbial communities on Earth (Takai and Nakamura 2011). Since the first discovery of black smoker vents inhabited by dense and unique chemosynthetic macrofaunal communities (Spiess et al. 1980), submarine hydrothermal systems and their associated biota have attracted great interest (e.g., Humphris et al. 1995; Van Dover 2000; Wilcock et al. 2004). Unlike most biological communities, in which photosynthetic organisms are the base of the food web, deep-sea hydrothermal vent ecosystems are dependent on primary production by symbiotic and free-living chemolithoautotrophic microorganisms that obtain energy from inorganic redox substances (e.g., $\mathrm{H}_{2} \mathrm{~S}, \mathrm{CO}_{2}, \mathrm{H}_{2}, \mathrm{CH}_{4}$, and $\mathrm{O}_{2}$ ) in hydrothermal fluids and ambient seawater (Karl, 1995; Kelley et al. 2002). Because of the unique features of deep-sea hydrothermal vent ecosystems, they are considered plausible analogues to the early ecosystems of Earth and also to extraterrestrial life on other planets and moons (e.g., Jannasch and Mottl 1985; Nealson et al. 2005; Takai et al. 2006a).

To date, more than 300 high-temperature hydrothermal vent systems have been identified at mid-ocean ridges (MOR), island arcs, and back-arc spreading centers (Hannington et al. 2011). Deep-sea hydrothermal fluids vary greatly in their chemical compositions due to subseafloor physical and chemical processes such as fluid-rock interactions, magmatic volatile inputs, and phase separation of hydrothermal fluids (Von Damm 1995; Butterfield et al. 2003; German and Von Damm 2004; Tivey 2007). Compositional variations in hydrothermal fluids (particularly energy and carbon sources) in turn affect biomass production and the diversity of hydrothermal vent-endemic communities. Consequently, clarifying the relationships among the geological background of hydrothermal environments, physical and chemical variations in hydrothermal fluids, and the compositional and functional diversity of chemosynthetic ecosystems has provided important information on the diversification and development of extant deep-sea hydrothermal ecosystems as well as the generation and sustenance of early ecosystems and possible extraterrestrial life forms.

In deep-sea hydrothermal vents, rapid mixing between hot reduced hydrothermal fluids and cold oxidized seawater provides chemical energy for microbial activity and biomass production. To quantify the in situ energetics of chemolithotrophic microorganisms in hydrothermal mixing environments, a thermodynamic model was first proposed and applied to a basalt-hosted hydrothermal system at $21^{\circ} \mathrm{N}$ on the East Pacific Rise (EPR) (McCollom and Shock 1997). Using batch-mixing models modified from this original model, thermodynamic calculations have been conducted for several hydrothermal vent systems at MOR and arc-backarc (ABA) hydrothermal systems (Shock and Holland 2004; Tivey 2004; McCollom 2007; Amend et al. 2011). These studies have demonstrated differing patterns in the potential energy yields of various in situ metabolic reactions in the mixing zones of these habitats, providing the theoretical basis for relationships between hydrothermal fluid chemistry and the diversity of hydrothermal vent-endemic biological communities. However, the hydrothermal systems studied were quite limited. In addition, the structures and functions of extant chemosynthetic biological communities, which have been characterized in many previous investigations, have not yet been integrated into development of these theoretical relationships.

Many studies have identified high compositional and functional diversity of chemosynthetic ecosystems in geographically and geologically diverse hydrothermal systems (e.g., in reviews by Huber and Holden 2008; Nakagawa and Takai 2008; Takai et al. 2006b). Some of these studies have noted possible relationships between the metabolic abundances and compositions of hydrothermal vent-endemic microbial communities and the chemical characteristics of hydrothermal vent fluids in deep-sea hydrothermal systems (Perner et al. 2007, 2010; Reysenbach and Shock 2002; Takai and Horikoshi 1999; Takai et al. 2001, 2004a). However, most of these studies were qualitative and focused mainly on the genetic and phylogenetic diversity of microbial communities and their constituents. Thus, the relationships between the abundance and composition of chemolithotrophic microbial communities and the geological and geochemical environments of global deep-sea hydrothermal systems remain unclear.

Takai and Nakamura $(2010,2011)$ first provided clear evidence of biogeochemical relationships among microbiological community development, the chemical composition of hydrothermal fluids, and the geological environment of deep-sea hydrothermal systems through both thermodynamic calculations of the potential energy yields of various in situ metabolic reactions and observed compositional and functional diversity of chemosynthetic ecosystems in the mixing zones of these habitats. However, examples of hydrothermal systems for this comparison were still scarce; thus, only microbial populations in chimney habitats adjacent to hightemperature hydrothermal fluids were characterized by quantitative cultivation techniques and included. In the present study, we conducted a more comprehensive evaluation of the relationships among variations in geology, geochemistry, and microbial metabolisms and the diversity of communities in global deep-sea hydrothermal environments, based on compilation of a substantial 
hydrothermal fluid chemistry data set and microbial communities in the mixing zones of a wide variety of habitats.

\section{Methods}

We compiled end-member fluid chemistry data for 89 hydrothermal vent sites (Additional file 1). Hydrothermal vent sites were included only if the data set contained complete chemical composition data essential for the thermodynamic calculations performed in this study, including $\mathrm{H}_{2}, \mathrm{H}_{2} \mathrm{~S}, \mathrm{CH}_{4}, \mathrm{CO}_{2}, \mathrm{Na}, \mathrm{Cl}, \mathrm{Ca}, \mathrm{K}, \mathrm{Fe}, \mathrm{Mn}$, and $\mathrm{Si}$. In addition, the data set included representative geological settings such as MOR hydrothermal systems in the Pacific, Atlantic, and Indian Oceans; ABA hydrothermal systems in the western Pacific region; and the sediment-associated (SED) hydrothermal systems in the eastern Pacific and Okinawa Trough (Figure 1).

The amount of metabolic energy available for production by chemolithotrophic microorganisms was evaluated as in Takai and Nakamura (2010, 2011). Four aerobic and anaerobic reactions were considered representative of chemolithotrophic energy metabolisms (Table 1). To simulate mixing of hydrothermal fluids with seawater in a seafloor hydrothermal system, we employed a thermodynamic reaction path model, following McCollom and Shock (1997), Shock and Holland
(2004), and McCollom (2007). The compositions of the hydrothermal solutions in the mixing zones were calculated from those of the end-member vent fluids and seawater (Additional file 1). The model calculation began with $1 \mathrm{~kg}$ of vent fluid and continued with addition of successive increments of seawater until a seawater to vent fluid mixing ratio of 1,000:1 was reached. In the mixing calculations, minerals were not allowed to precipitate and all redox reactions were prohibited, while acid-base reactions were allowed to equilibrate. In addition, the temperatures of the calculated mixed solutions were assumed to scale linearly with the temperatures of the end-members, ignoring conductive cooling and/or heating.

The overall Gibbs free energy for the metabolic reactions was calculated using the following equation:

$$
\Delta G_{r}=\Delta G_{r}^{\circ}+R T \ln Q_{r}
$$

where $\Delta G_{r}$ is the Gibbs free energy of the reaction, $\Delta G_{r}^{\circ}$ is the standard-state Gibbs free energy of the reaction, $R$ is the universal gas constant, $T$ is the temperature in Kelvin, and $Q_{r}$ is the activity quotient of the compounds involved in the reaction. The $Q_{r}$ term takes into account the contribution of the fluid composition to the Gibbs free energy of each reaction, determined based on the

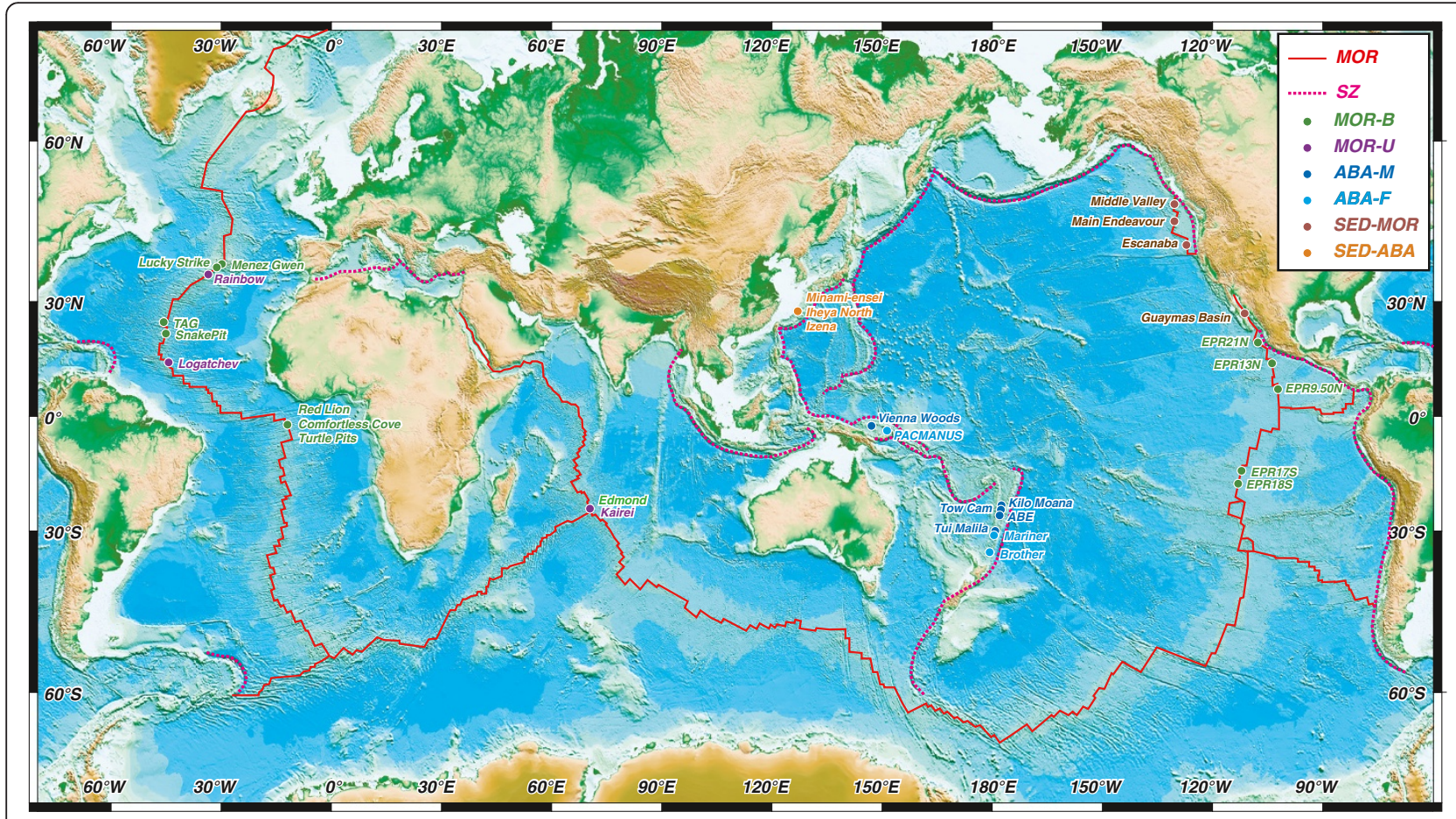

Figure 1 Index map showing mid-ocean ridges and subduction zones with active hydrothermal vents used in this study. Abbreviations: MOR, mid-ocean ridge; $S Z$, subduction zone; MOR-B, basalt-hosted system in a mid-ocean ridge setting; MOR-U, ultramafic rock-hosted system in a mid-ocean ridge setting; ABA-M, mafic rock-hosted system in an arc-backarc setting; ABA-F, felsic rock-hosted system in an arc-backarc setting; SED-MOR, sediment-associated system in a mid-ocean ridge setting; SED-ABA, sediment-associated system in an arc-backarc setting. 
Table 1 Metabolic reactions for chemolithoautotrophy considered in this study

\begin{tabular}{|c|c|c|c|}
\hline Energy metabolism & Overall chemical reaction & Identified (I)/cultured (C) & $\Delta G_{\mathrm{r} 2,250}^{\circ}(\mathrm{kJ})^{\mathrm{a}}$ \\
\hline \multicolumn{4}{|l|}{ Aerobic reactions } \\
\hline Aerobic methanotrophy & $\mathrm{CH}_{4}+2 \mathrm{O}_{2}=\mathrm{CO}_{2}+2 \mathrm{H}_{2} \mathrm{O}$ & I and $C$ & -860.7 \\
\hline Hydrogenotrophic $\mathrm{O}_{2}$ reduction & $\mathrm{H}_{2}+1 / 2 \mathrm{O}_{2}=\mathrm{H}_{2} \mathrm{O}$ & I and C & -264.4 \\
\hline Thiotrophic ( $\mathrm{H}_{2} \mathrm{~S}$-oxidizing) $\mathrm{O}_{2}$ reduction & $\mathrm{H}_{2} \mathrm{~S}+2 \mathrm{O}_{2}=\mathrm{SO}_{4}^{2-}+2 \mathrm{H}^{+}$ & I and $C$ & -758.2 \\
\hline Fe(II)-oxidizing $\mathrm{O}_{2}$ reduction & $\mathrm{Fe}^{2+}+1 / 4 \mathrm{O}_{2}+\mathrm{H}^{+}=\mathrm{Fe}^{3+}+1 / 2 \mathrm{H}_{2} \mathrm{O}$ & I and C & -52.6 \\
\hline \multicolumn{4}{|l|}{ Anaerobic reactions } \\
\hline Hydrogenotrophic methanogenesis & $\mathrm{H}_{2}+1 / 4 \mathrm{CO}_{2}=1 / 4 \mathrm{CH}_{4}+1 / 2 \mathrm{H}_{2} \mathrm{O}$ & I and C & -49.2 \\
\hline Hydrogenotrophic $\mathrm{SO}_{4}$ reduction & $\mathrm{H}_{2}+1 / 4 \mathrm{SO}_{4}^{2-}+1 / 2 \mathrm{H}^{+}=1 / 4 \mathrm{H}_{2} \mathrm{~S}+\mathrm{H}_{2} \mathrm{O}$ & I and $C$ & -74.9 \\
\hline Hydrogenotrophic Fe(III) reduction & $\mathrm{H}_{2}+2 \mathrm{Fe}^{3+}=2 \mathrm{Fe}^{2+}+2 \mathrm{H}^{+}$ & I and $C$ & -159.2 \\
\hline Anoxic methanotrophy with $\mathrm{SO}_{4}$ reduction & $\mathrm{CH}_{4}+\mathrm{SO}_{4}^{2-}=\mathrm{HCO}_{3}^{-}+\mathrm{HS}^{-}+\mathrm{H}_{2} \mathrm{O}$ & I but not yet $C$ & -30.1 \\
\hline
\end{tabular}

${ }^{\mathrm{a}} \mathrm{Standard}$-state Gibbs free energy of the metabolic reactions at $2^{\circ} \mathrm{C}, 250 \mathrm{bar}$.

chemical composition of the mixed fluid estimated from the reaction path calculations. The energy available from the metabolic reactions as a function of temperature (equivalent to the mixing ratio) was calculated by multiplying the calculated Gibbs free energy for the reaction at each temperature by the concentrations of the reactants in the mixed fluid. This method takes into account the stoichiometry of the reaction and the reactants that are limiting, multiplied by the total amount of mixed fluid at that temperature (McCollom and Shock 1997; McCollom 2007).

This calculation yields an estimate of the maximum energy that is potentially available from the metabolic reactions per kilogram of mixed fluid. We used the average $\Delta G_{r}$ values for four temperature ranges: $<25^{\circ} \mathrm{C}, 25^{\circ} \mathrm{C}$ to $45^{\circ} \mathrm{C}, 45^{\circ} \mathrm{C}$ to $80^{\circ} \mathrm{C}$, and $80^{\circ} \mathrm{C}$ to $125^{\circ} \mathrm{C}$, representing the chemolithotrophic metabolisms of psychrophilic, mesophilic, thermophilic, and hyperthermophilic microbial organisms, respectively.

\section{Geological settings and geochemical characteristics of seafloor hydrothermal systems}

As noted above, we compiled data for 89 deep-sea hydrothermal vent sites located in various geological settings (Figure 1), including MOR, ABA, and SED hydrothermal systems. These can be further subdivided into the following six categories: basalt-hosted systems in MOR settings (MOR-B), ultramafic rock-associated systems in MOR settings (MOR-U), mafic rock-hosted systems in ABA settings (ABA-M), felsic rock-hosted systems in ABA settings (ABA-F), SED systems in MOR settings (SED-MOR), and SED systems in ABA settings (SED-ABA).

The molecular and elemental compositions of $\mathrm{H}_{2}$, $\mathrm{H}_{2} \mathrm{~S}, \mathrm{CH}_{4}, \mathrm{CO}_{2}, \mathrm{Na}, \mathrm{Ca}, \mathrm{K}, \mathrm{Fe}, \mathrm{Mn}$, and $\mathrm{Si}$ as well as the $\mathrm{pH}$ values of the end-member hydrothermal fluids from these sites are plotted against the $\mathrm{Cl}$ content in Figure 2. Nearly all substances exhibited some degree of positive or negative correlation to the $\mathrm{Cl}$ content, reflecting the influence of phase separation of hydrothermal fluids. Here, we focus on hydrothermal fluids with similar $\mathrm{Cl}$ concentrations to seawater in providing a brief overview of the geological settings and corresponding principal characteristics of their hydrothermal environments.

\section{MOR hydrothermal systems}

The global MOR system is the largest mountain chain in the world, with a total length of more than $60,000 \mathrm{~km}$. Magma production in the MOR system far exceeds that in any other tectonic environment, accounting for more than $60 \%$ by volume of the total annual flux of magma from the mantle to the crust (Fisher and Schmincke 1984; Schmincke 2004). Therefore, the MOR system is the locus of the greatest amount of hydrothermal activity on Earth. Most MOR hydrothermal vents are hosted by basalt (often termed mid-ocean-ridge basalt). Therefore, many studies of deep-sea hydrothermal systems have focused mainly on basalt-hosted hydrothermal systems (Karl 1995; Kelley et al. 2002). However, in recent years, increasing attention has been paid to hydrothermal systems associated with ultramafic rocks present in the MOR (Kelley et al. 2001, 2005; Früh-Green et al. 2004), because the geochemical characteristics of ultramafic rock-hosted hydrothermal fluids are significantly different from those of basalt-hosted ones (Charlou et al. 2002).

Hydrothermal fluids from basalt-hosted systems are characterized by enrichment in base metals, a generally neutral or weakly acidic in situ $\mathrm{pH}$, and strongly reducing conditions compared to seawater, due to subseafloor hydrothermal reactions between basaltic rocks and seawater at high temperature and pressure (Seyfried et al. 1991; Wetzel and Shock 2000). However, the fluids from ultramafic rock-associated systems are often characterized by an abundance of dissolved $\mathrm{H}_{2}$ and $\mathrm{CH}_{4}$ compared to basalt-hosted hydrothermal fluids (Figure 2) 


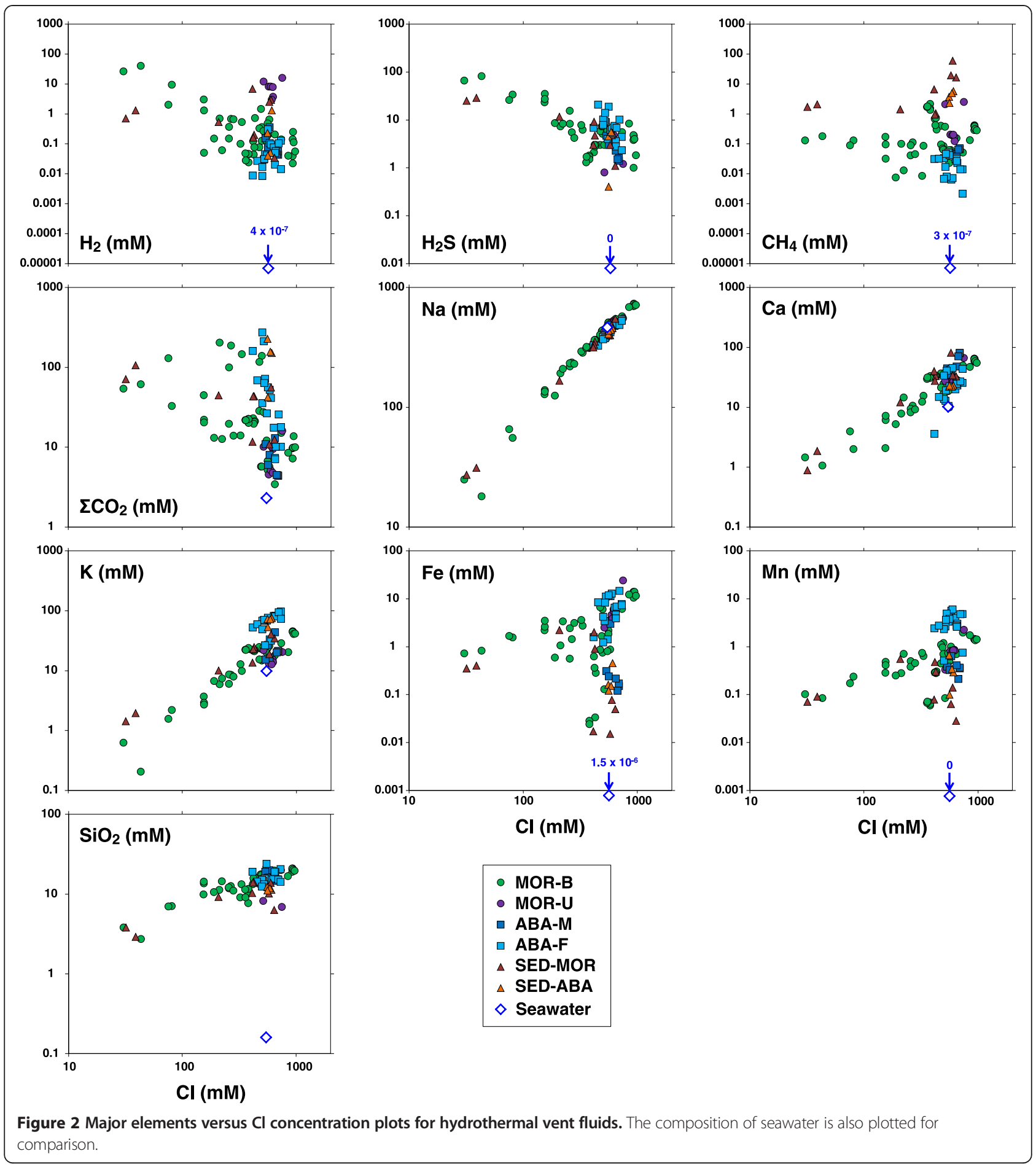

(Charlou et al. 1998, 2002). This is attributed to differences in the mineralogy and bulk chemistry of the rocks, resulting in a substantially different alteration reaction known as serpentinization (Janecky and Seyfried 1986; Wetzel and Shock 2000; Allen and Seyfried 2003). $\mathrm{H}_{2}$ concentrations of 12 to $16 \mathrm{mmol} / \mathrm{kg}$ (roughly 1 to 2 orders of magnitude higher than in basalt-hosted hydrothermal fluids) due to serpentinization have been reported in ultramafic rock-hosted deep-sea hydrothermal vent fluids (Additional file 1) (Charlou et al. 2002; Kelley et al. 2005). In addition, enrichment of $\mathrm{CH}_{4}$ in ultramafic rock-associated systems is likely associated with 
reduction of $\mathrm{CO}_{2}$ to $\mathrm{CH}_{4}$ under highly reducing (high $\mathrm{H}_{2}$ ) conditions.

\section{ABA hydrothermal systems}

Although significant global magma production occurs in the MOR, the second most active volcanic area is the subduction zone (Fisher and Schmincke 1984; Schmincke 2004), where ABA volcanic systems develop. Some arc volcanoes are subaerial, particularly in continental arc settings, whereas more than $40 \%$ of volcanic arcs are oceanic island arcs where most volcanoes are submarine (Leat and Larter 2003). In oceanic island arcs and associated backarc basins, many deep-sea hydrothermal vent sites hosted by active submarine ABA volcanisms have been discovered (Ishibashi and Urabe 1995; Gamo et al. 2006). The chemical characteristics of these ABA hydrothermal systems are significantly different from those of MOR hydrothermal systems, although they share many common features derived from the basic reactions and processes of subseafloor hydrothermal circulation. In particular, ABA hydrothermal fluids are characterized by large variations in chemical composition (Ishibashi and Urabe 1995; Gamo et al. 2006). This chemical variability is primarily attributed to a variety of host-rock compositions (from basaltic to rhyolitic), abundant input of volatile elements from magmas (e.g., $\mathrm{CO}_{2}$ and $\mathrm{SO}_{2}$ ), and the variable water depth (shallow to deep) of the submarine volcanoes.

ABA hydrothermal systems hosted by mafic rocks exhibit chemical characteristics similar to those of basalthosted hydrothermal systems at the MOR (Figure 2). In contrast, systems hosted by felsic rocks are generally characterized by lower $\mathrm{pH}$, higher metal concentrations, and a variable redox state compared to mafic rockhosted hydrothermal systems (Figure 2). In addition, because of the subduction of hydrated ocean crust beneath volcanic arcs and back-arc basins as well as the potential involvement of more evolved felsic magmas, the volatile content $\left(\mathrm{H}_{2} \mathrm{O}, \mathrm{CO}_{2}\right.$, and $\left.\mathrm{SO}_{2}\right)$ of magmas in $\mathrm{ABA}$ settings is much higher than that in MOR settings (e.g., Gamo et al. 1997; Embley et al. 2007). ABA hydrothermal systems are also characterized by wide variations in water depth, and most are significantly shallower than typical MOR hydrothermal systems (Figure 3). This results in variations in phase separation (boiling) and hydrothermal fluid temperatures in the subseafloor reaction zones, which significantly affect the chemical composition of the hydrothermal fluids. The maximum temperatures of the hydrothermal vent fluids in the compiled data were clearly controlled by the two-phase boundary of seawater (Figure 3).

\section{SED hydrothermal systems}

Some hydrothermal vent sites are covered with sediments, which influence the chemical composition of

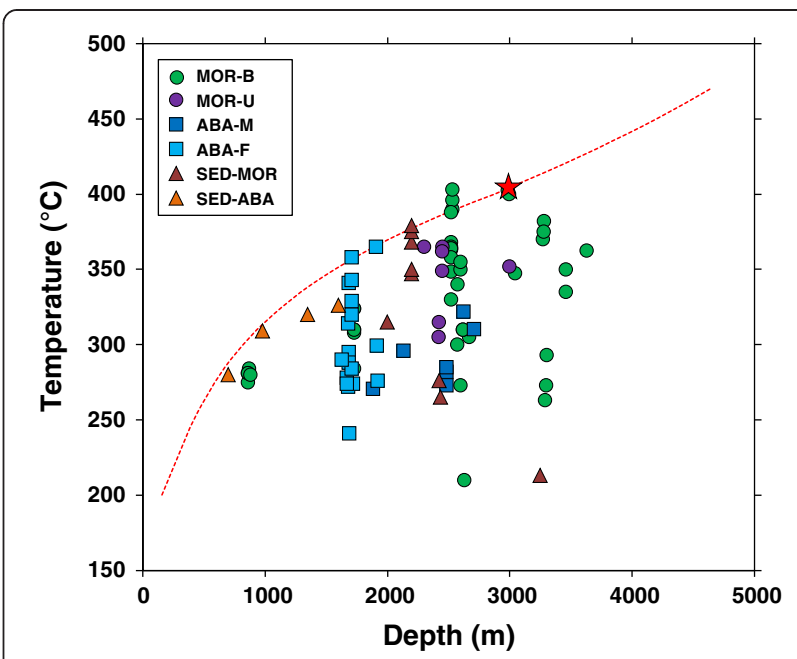

Figure 3 Maximum temperature conditions versus water depth for individual vent areas. Two-phase curve for seawater (dashed line) is also plotted with the liquid field to the lower right of the curve and the liquid + vapor field to the upper left of the curve. The star represents the critical point of seawater at $407^{\circ} \mathrm{C}$ and 298 bar. The maximum temperature of nearly all of the vent fluids is limited by the two-phase boundary.

their hydrothermal fluids. SED hydrothermal systems are found in both MOR (e.g., Juan de Fuca, Middle Valley, Escanaba Trough, and Guaymas Basin) and ABA (e.g., Okinawa Trough) settings in which hydrothermal vent sites are in close proximity to continental runoff sources. Irrespective of differences in tectonic setting or hostrock composition, SED hydrothermal systems have characteristic chemical compositions, e.g., relatively high $\mathrm{pH}$, low metal content, and high $\mathrm{CH}_{4}$ and $\mathrm{NH}_{3}$ concentrations (German and Von Damm 2004). There are only minor differences in chemical composition between SED hydrothermal systems in MOR and ABA settings (Figure 2). Thus, the chemical features of SED hydrothermal vent fluids are more strongly affected by the sediment than by the tectonic setting or host-rock composition.

\section{Factors controlling hydrothermal fluid chemistry}

It is believed that hydrothermal fluid flux is primarily controlled by the crust (magma) production rate, because magmatic heat derived from creation of new oceanic crust (cooling from $1,200^{\circ} \mathrm{C}$ to $350^{\circ} \mathrm{C}$ ) heats hydrothermal fluids from $2^{\circ} \mathrm{C}$ to $350^{\circ} \mathrm{C}$ (e.g., Elderfield and Schultz 1996). Based on this, Kawahata et al. (2001) estimated that the maximum volume of high-temperature hydrothermal fluid is twice that of the upper oceanic crust (the volcanic and sheeted dike sequence) and if $65 \%$ to $85 \%$ of the rocks are altered to secondary minerals, the volumetric water/rock ratio would be 2.3 to 3.1. This clearly suggests that high-temperature hydrothermal fluids are generated under rock-dominated (low water/rock ratio) conditions (Kawahata et al. 2001). Therefore, the chemical compositions of hydrothermal fluids are 
predominantly controlled by water-rock reactions and fluid-mineral equilibria (Seyfried et al. 1991; Shock 1992; Seyfried and Ding 1995). Thus, host-rock geochemistry is one of the most important factors controlling hydrothermal fluid chemistry. In addition to the chemical compositions of host rocks, however, other processes such as input of volatiles from magmas, phase separation of hydrothermal fluids, and interactions with sediment also have a significant impact on the observed compositions of hydrothermal fluids.

\section{Chemical composition of host rocks}

Differences in the rock types in the reaction zone can lead to large variations in the hydrothermal fluid chemistry, because the bulk chemical composition and primary minerals in the source rock control the reaction sequences and their chemical equilibria.

Mafic rocks Most ocean basins (including MOR and ABA settings) are of mafic composition (mainly basaltic). The chemical systematics of mafic rock-seawater systems (particularly basalt-seawater systems) have been well characterized based on field observations, hydrothermal experiments, and theoretical studies (Bischoff and Dickson 1975; Mottl and Holland 1978; Seyfried and Mottl 1982; Mottl 1983; Reed 1983; Bowers and Taylor 1985; Seyfried 1987; Von Damm 1990, 1995; Seyfried et al. 1988, 1991; Shock 1992; Saccocia et al. 1994; Wetzel and Shock 2000; Butterfield et al. 2003; Nakamura et al. 2007).

Basalt-hosted hydrothermal fluids have relatively low $\mathrm{pH}$ at $25^{\circ} \mathrm{C}$ and $1 \mathrm{~atm}$ (generally 3 to 4 ) and notable enrichment in base metals (e.g., Fe and $\mathrm{Mn}$ ) and dissolved gases (e.g., $\mathrm{H}_{2}, \mathrm{CO}_{2}$, and $\mathrm{CH}_{4}$ ) compared to seawater (Figure 2). The in situ $\mathrm{pH}$ of the basalt-hosted vent fluids are neutral to weakly acidic, significantly different from the $\mathrm{pH}$ measured at $25^{\circ} \mathrm{C}$ and $1 \mathrm{~atm}$ in laboratory experiments (German and Von Damm 2004). This discrepancy is mainly caused by dissociation of $\mathrm{H}^{+}$-bearing aqueous complexes (e.g., $\mathrm{HCl}^{0}$ ) due to cooling during sample processing (Shock et al. 1989; Seyfried et al. 1991; Ding and Seyfried 1992; Ding et al. 2005). Another possible mechanism of $\mathrm{pH}$ change is precipitation of metal sulfides below the seafloor, producing protons (German and Von Damm 2004).

In high-temperature MOR vent fluids, most metals are enriched by up to 7 to 8 orders of magnitude compared to seawater. The stability of chloride complexes (e.g., $\mathrm{FeCl}_{2}^{0}$ ) increases with increasing temperature, and therefore, most metal ions are present in high-temperature fluids as chloride complexes (Helgeson et al. 1981; Ding and Seyfied 1992). The substantial increase in the metal solubility produces the high concentrations in the vent fluids.
Basalt-hosted hydrothermal fluids are also highly reducing, as evidenced by the presence of $\mathrm{H}_{2} \mathrm{~S}$ rather than $\mathrm{SO}_{4}$, as well as by significant amounts of $\mathrm{H}_{2}$, $\mathrm{CH}_{4}, \mathrm{Fe}^{2+}$, and $\mathrm{Mn}^{2+}$. These chemical features are generally consistent with phase-equilibrium calculations involving the observed primary and secondary minerals (feldspar, chlorite, epidote, quartz, magnetite, anhydrite, pyrite, and pyrrhotite) and seawater at in situ hydrothermal fluid temperatures and pressures (Bowers et al. 1988; Seyfried et al. 1988, 1999; Saccocia and Seyfried 1990; Seyfried and Ding 1995; McCollum and Shock 1998; Wetzel and Shock 2000). Time-series measurements of chemical compositions of hydrothermal fluids in MOR regions have indicated steady-state concentrations of dissolved species (Campbell et al. 1988; Bowers et al. 1988; Butterfield et al. 1994; Von Damm 1988, 1995, 2000), reflecting clear solubility control by mineral phases in the subseafloor reaction zones and recharge zones.

Ultramafic rocks Compared with hydrothermal fluids in mafic rock-hosted systems, ultramafic rock-associated hydrothermal fluids are characterized by conspicuous enrichment in $\mathrm{H}_{2}$ in the presence or absence of phase separation processes (Figure 2). Production of $\mathrm{H}_{2}$ during serpentinization of ultramafic rocks results from reaction of water with $\mathrm{Fe}^{2+}$-bearing minerals, primarily olivine and pyroxene. In these reactions, $\mathrm{Fe}^{2+}$ is partially oxidized to $\mathrm{Fe}^{3+}$ by the water, resulting in precipitation of magnetite in the serpentinite. The water reduced by the $\mathrm{Fe}^{2+}$ also produces $\mathrm{H}_{2}$. One of the important chemical features of ultramafic rocks that constrains abundant $\mathrm{H}_{2}$ production during serpentinization is relatively low $\mathrm{Al}$ concentrations. Low $\mathrm{Al}$ activity results in formation of alteration minerals (particularly serpentines and brucite) that have a tendency to exclude $\mathrm{Fe}^{2+}$ from their structure. This leads to oxidation of $\mathrm{Fe}^{2+}$ by water to form magnetite. In contrast, because mafic rocks have higher $\mathrm{Al}$ contents than ultramafic rocks, a much greater proportion of the $\mathrm{Fe}^{2+}$ is sequestered in $\mathrm{Al}$ bearing alteration minerals (e.g., chlorite), limiting oxidation of $\mathrm{Fe}^{2+}$ to $\mathrm{Fe}^{3+}$. Thus, hydrothermal alteration of mafic rocks generates much lower amounts of $\mathrm{H}_{2}$ and magnetite than serpentinization of ultramafic rocks, even though the Fe content of basaltic rocks is higher than that of ultramafic rocks. Basaltic rock-hosted vent fluids typically exhibit $\mathrm{H}_{2}$ concentrations of $<1 \mathrm{mmol} /$ $\mathrm{kg}$, whereas $>10 \mathrm{mmol} / \mathrm{kg} \mathrm{H}_{2}$ has frequently been reported for ultramafic rock-associated fluids (Additional file 1). The potential for even higher $\mathrm{H}_{2}$ concentrations (>100 mmol/ $/ \mathrm{kg}$ ) has been suggested by both petrological (Frost 1985; Alt and Shanks 1998) and experimental (Berndt et al. 1996; McCollom and Seewald 2001) studies. 
In addition, ultramafic rock-associated hydrothermal fluids are often characterized by $\mathrm{CH}_{4}$ enrichment (Figure 2). Although the origin of $\mathrm{CH}_{4}$ in these fluids is controversial, it is generally thought to be derived from reduction of $\mathrm{CO}_{2}$ by high concentrations of $\mathrm{H}_{2}$ through abiotic methanogenesis (Nakamura et al. 2009). However, the hydrothermal fluid $\mathrm{CH}_{4}$ concentrations are always disequilibrated with the concomitant $\mathrm{H}_{2}$ and $\mathrm{CO}_{2}$ concentrations, suggesting that the subseafloor hydrothermal circulation system is an open system with respect to $\mathrm{CH}_{4}$ content. Enriched $\mathrm{CH}_{4}(>0.5 \mathrm{mmol} / \mathrm{kg}$ ) has also been observed in hydrothermal fluids from certain basalt-hosted systems at the MOR (Figure 2; Lucky Strike and Menez Gwen hydrothermal fields) (Additional file 1). Both of these fields are located in the northern Mid-Atlantic Ridge, where several ultramafic rockassociated hydrothermal systems have been discovered. Based on geological and geochemical lines of evidence, it has been suggested that the high $\mathrm{CH}_{4}$ concentrations in these basalt-hosted hydrothermal fluids were caused by serpentinization of ultramafic rocks somewhere in the subseafloor (Charlou et al. 2000).

Felsic rocks Hydrothermal systems hosted by felsic rocks have been identified only in ABA settings (Figure 1). Felsic rock-hosted hydrothermal fluids are characterized by relatively low $\mathrm{pH}$ and enrichment in $\mathrm{H}_{2} \mathrm{~S}, \mathrm{CO}_{2}, \mathrm{~K}, \mathrm{Mn}$, and $\mathrm{Fe}$ compared to mafic rock-hosted fluids (Figure 2). The chemical characteristics of felsic rock-hosted hydrothermal fluids are generally consistent with experimental results for seawater-felsic rock interactions (e.g., Hajash and Chandler 1981). For example, felsic rocks contain high concentrations of incompatible elements such as K. Enrichment of $\mathrm{K}$ in felsic rock-hosted fluids originates from the bulk rock composition. In addition, the lower $\mathrm{pH}$ is attributed to the low ability of felsic rocks to consume $\mathrm{H}^{+}$in solution. The $\mathrm{pH}$ of a hydrothermal solution is lowered by removal of $\mathrm{Mg}^{2+}$ via precipitation of $\mathrm{Mg}$-hydroxysulfate during heating of the seawater (Bischoff and Seyfried 1978) and by formation of Mg-bearing alteration minerals (e.g., smectite and chlorite) during seawater-rock interactions (Mottl 1983). In a basalt-seawater system, the $\mathrm{H}^{+}$ generated in the fluid is consumed by dissolution of $\mathrm{Ca}$ from the reacted rocks (Seyfried and Mottl 1982; Mottl 1983). Mg-Ca exchange reactions control the fluid $\mathrm{pH}$ to approximately neutral under in situ conditions (Seyfried and Mottl 1982; Wetzel and Shock 2000). However, because felsic rocks are relatively depleted in $\mathrm{Ca}$, their ability to buffer $\mathrm{pH}$ changes is significantly lower than that of their mafic counterparts.

Low $\mathrm{pH}$ in hydrothermal fluids promotes leaching of heavy metals through water-rock interactions. This ultimately results in high concentrations of heavy metals, although the initial concentrations of heavy metals in felsic rocks are lower than those in basaltic rocks. The Fe and Mn concentrations in deep-sea hydrothermal fluids are correlated not only with $\mathrm{Cl}$ concentrations but also with $\mathrm{pH}$ (Figure 4). Moreover, the $\mathrm{Fe} / \mathrm{Cl}$ and $\mathrm{Mn} / \mathrm{Cl}$ ratios for hydrothermal fluids exhibit strong correlations with $\mathrm{pH}$ (Figure 4). This clearly shows that the concentrations of heavy metals in deep-sea hydrothermal fluids are mainly controlled by the $\mathrm{pH}$ of the hydrothermal fluids.

\section{Inputs of magmatic volatiles}

Enrichment of $\mathrm{H}_{2} \mathrm{~S}$ and $\mathrm{CO}_{2}$ in felsic rock-hosted hydrothermal fluids cannot be explained only by water-rock interactions. Instead, enrichment in these volatiles can be caused by inputs of magmatic volatiles into hydrothermal systems. ABA magmas (particularly those that are felsic in composition) have very high concentrations of volatile elements and molecules, and hydrothermal fluids that are highly enriched in sulfur and/or $\mathrm{CO}_{2}$ have been observed in ABA hydrothermal systems, mainly hosted by more siliceous rocks, e.g., andesite, calcite, and rhyolite rather than by basalt (Gamo et al. 1997; Sakai et al. 1990; Inagaki et al. 2006; Lupton et al. 2006, 2008). Therefore, enrichment in $\mathrm{CO}_{2}$ and $\mathrm{H}_{2} \mathrm{~S}$ of felsic rock-hosted hydrothermal fluids is likely due to significant inputs of magmatic volatiles into these hydrothermal systems.

Dissolution of $\mathrm{CO}_{2}$ gas into a hydrothermal fluid results in production of $\mathrm{H}^{+}$in the fluid via the following reaction:

$$
\mathrm{CO}_{2}+\mathrm{H}_{2} \mathrm{O}=\mathrm{HCO}_{3}{ }^{-}+\mathrm{H}^{+} \text {. }
$$

Compared to that for $\mathrm{SO}_{2}$ (see below), the dissociation constant of this reaction is much smaller, particularly under high-temperature conditions. It is therefore believed that the effect of $\mathrm{CO}_{2}$ on the fluid $\mathrm{pH}$ is not very significant. However, segregation of $\mathrm{CO}_{2}$ from upwelling hydrothermal fluids in the subseafloor can result in consumption of $\mathrm{H}^{+}$in the fluid, increasing the $\mathrm{pH}$. Even a small $\mathrm{pH}$ increase during ascent of the hydrothermal fluid can cause subseafloor precipitation of metal-sulfide minerals, resulting in low heavy metal concentrations in the hydrothermal fluids. This process would be expected in hydrothermal systems with significant inputs of $\mathrm{CO}_{2}$ but not $\mathrm{SO}_{2}$ from magma, such as hot spot-influenced MOR hydrothermal systems and basalt-hosted arcbackarc hydrothermal systems.

Volatile sulfur species in the magma have a more significant effect on deep-sea hydrothermal systems. The predominant gaseous sulfur species in magma are $\mathrm{SO}_{2}$ and $\mathrm{H}_{2} \mathrm{~S}$ (Wallace and Edmonds, 2011). Although dissolution of $\mathrm{H}_{2} \mathrm{~S}$ does not significantly affect hydrothermal fluid chemistry, that of $\mathrm{SO}_{2}$ into hydrothermal fluids 


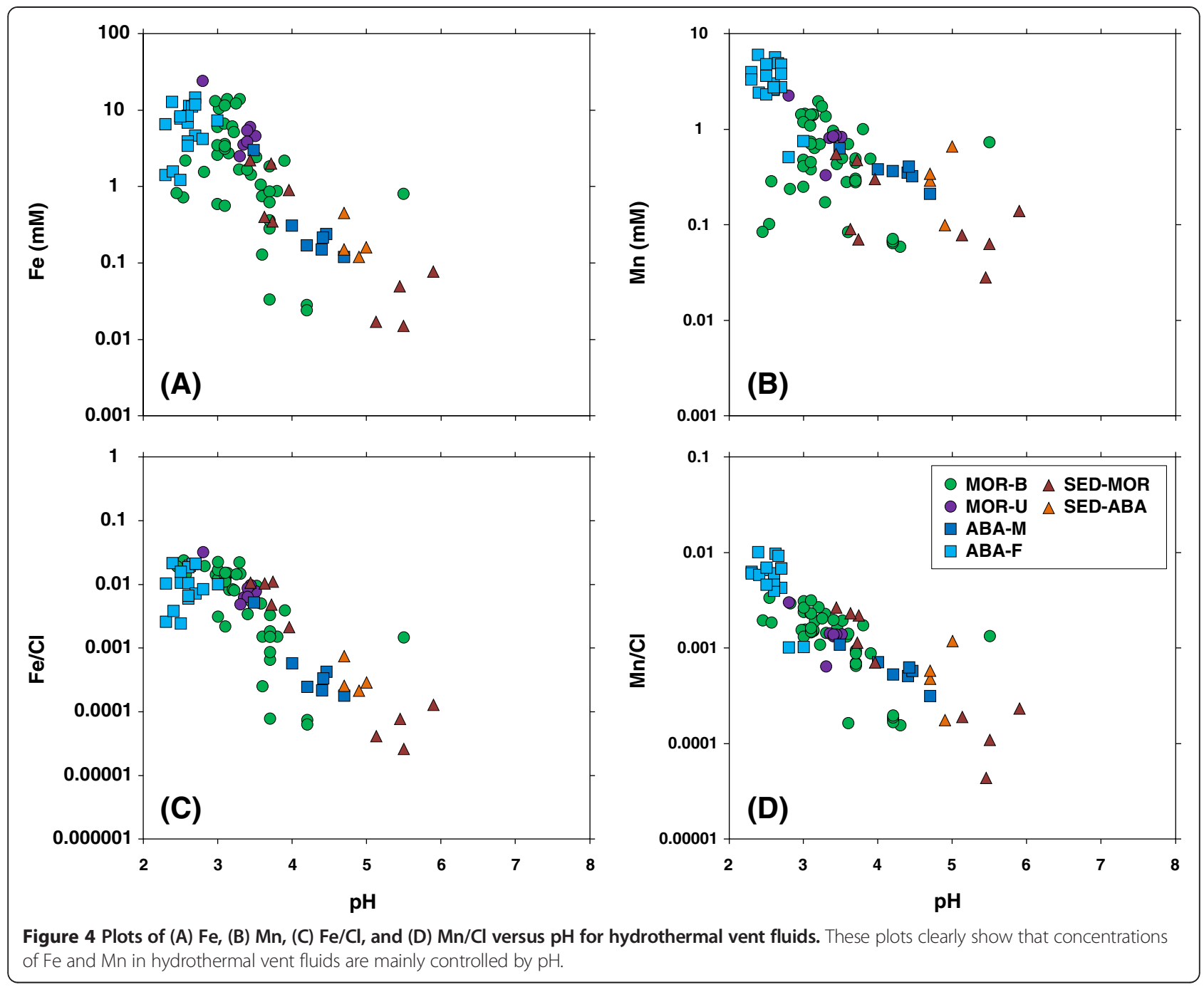

increases the $f_{\mathrm{O}_{2}}$ and sulfuric acid in the fluids via the following reactions:

$$
\begin{aligned}
& 2 \mathrm{SO}_{2}+2 \mathrm{H}_{2} \mathrm{O}=2 \mathrm{H}_{2} \mathrm{~S}^{0}+3 \mathrm{O}_{2} \\
& 2 \mathrm{SO}_{2}+\mathrm{O}_{2}+2 \mathrm{H}_{2} \mathrm{O}=2 \mathrm{HSO}_{4}^{-}+2 \mathrm{H}^{+} .
\end{aligned}
$$

Once the $f_{\mathrm{O}_{2}}$ of the hydrothermal fluid reaches the sulfate-sulfide boundary via reaction (3), sulfuric acid is produced by reaction (4). The presence of sulfuric acid can cause a significant decrease in $\mathrm{pH}$. Because the solubility of heavy metals is quite sensitive to $\mathrm{pH}$, the $\mathrm{pH}$ decrease caused by $\mathrm{SO}_{2}$ promotes dissolution of heavy metals from the reacted rocks. Volatile inputs from magmas occur intermittently, and even during such activity, the chemistry of hydrothermal fluids is controlled by reactions induced by both volatile inputs and waterrock interactions. Therefore, it is likely that the chemical composition of the fluids, as is typical of open and dynamic systems, significantly varies with space and time.
Nevertheless, felsic rock-hosted hydrothermal systems affected by magmatic volatile inputs clearly exhibit high concentrations of base metals and low pH (Figure 4).

\section{Phase separation}

As described above, the concentrations of all components in hydrothermal fluids exhibited positive or negative correlations with $\mathrm{Cl}$, except for $\mathrm{H}_{2}, \mathrm{CO}_{2}$, and $\mathrm{CH}_{4}$ in several samples affected by serpentinization of ultramafic rocks, $\mathrm{CO}_{2}$ inputs from magma, and $\mathrm{CH}_{4}$ inputs from sedimentary organic matter and/or microbial processes (Figure 2). Deep-sea hydrothermal fluids often reach temperatures high enough that they separate into vapor and brine phases. The phase separation temperature depends primarily on the pressure conditions (i.e., water depth) of the hydrothermal system. The observed temperatures of hydrothermal fluids from various vent sites were clearly limited by the two-phase boundary of seawater (Bischoff and Pitzer 1989) (Figure 3). Phase separation and subsequent remixing of the vapor 
and brine phases produce hydrothermal fluids with a wide range of salinities, from 1 order of magnitude lower to several times higher than that of seawater (Figure 2).

The chemical properties of the vapor and brine phases are quite different from each other and from their parent fluid, because each of the chemical species in the parent fluid is distributed preferentially into the vapor and liquid phases according to their physical and chemical properties during phase separation (Butterfield et al. 2003; Foustoukos and Seyfried 2007). The concentrations of gaseous species greatly increased with decreasing $\mathrm{Cl}$ concentration, indicating the strong affinity of these volatile components for the vapor phase (Figure 2). In contrast, the positive correlations between the $\mathrm{Cl}$ concentration and other dissolved species that are primarily ionic (e.g., $\mathrm{Na}^{+}$and $\mathrm{Cl}^{-}$) indicate the strong affinity of these species for the liquid phase. In addition, the relationships between the $\mathrm{Cl}$ concentration and the ratios of elements to chloride clearly showed a strong increase in the ratios of gaseous species to chloride with decreasing $\mathrm{Cl}$ concentration (Figure 5 ). The $\mathrm{Si} / \mathrm{Cl}$ ratio also slightly increased with decreasing $\mathrm{Cl}$ concentration. This indicates that, in addition to gaseous species, neutral species such as $\mathrm{SiO}_{2}^{0}$ have some affinity for the vapor phase. On the other hand, there was little change in the ratios of ionic species with $\mathrm{Cl}$ concentration as a result of phase separation, indicating that they all partition strictly into the brine phase. These chemical behaviors of the dissolved species during the phase separation and partitioning into hydrothermal fluids result in formation of low-Cl, vapor-dominated fluids enriched in gases and of residual brines enriched in ionic species and depleted in gases.

\section{Presence of sediments}

SED hydrothermal systems have chemical compositions distinct from those of other hydrothermal fluids. Compared to those of sediment-starved MOR and ABA hydrothermal systems, SED hydrothermal fluids generally have relatively high $\mathrm{pH}$, lower heavy metal contents, and higher $\mathrm{CH}_{4}$ and $\mathrm{NH}_{4}^{+}$concentrations (Figure 2) (German and Von Damm, 2004). The very high $\mathrm{CH}_{4}$ concentrations of hydrothermal fluids in SED systems are attributed to thermal decomposition of organic matter at high temperatures during hydrothermal reactions at discharge zones and/or microbial methanogenesis at relatively low temperatures at sedimentary recharge zones (Lilley et al. 1993; Kawagucci et al. 2011, 2013). Likewise, the source of $\mathrm{NH}_{4}^{+}$in SED hydrothermal systems is considered to be thermal decomposition and microbial ammonification of organic matter (Kawagucci et al. 2011, 2013). High concentrations of $\mathrm{NH}_{4}^{+}$in these hydrothermal fluids provide an $\mathrm{NH}_{3} / \mathrm{NH}_{4}^{+}$buffer that maintains the relatively high $\mathrm{pH}$ of the fluid (German and Von Damm, 2004). This greatly decreases the solubility of metal-sulfide minerals, leading to low heavy metal concentrations in the hydrothermal-vent fluids.

\section{Effects of hydrothermal fluid chemistry on the bioavailable energy yield}

The chemosynthetic primary producers that sustain deep-sea hydrothermal vent ecosystems utilize inorganic substances (e.g., $\mathrm{H}_{2} \mathrm{~S}, \mathrm{CO}_{2}, \mathrm{H}_{2}$, and $\mathrm{CH}_{4}$ ) derived from hydrothermal vent fluids as energy and carbon sources. Thus, deep-sea hydrothermal vent ecosystems should be at least partially controlled by the chemical composition of the hydrothermal fluids. The effects of hydrothermal fluid compositions on deep-sea hydrothermal vent ecosystems based on the energy yields available to various chemolithotrophic metabolisms are described below.

\section{Hydrogen sulfide $\left(\mathrm{H}_{2} \mathrm{~S}\right)$}

In all of the deep-sea hydrothermal systems in all settings, the potential energy yields for sulfur-oxidizing chemolithotrophy (thiotrophy) using $\mathrm{H}_{2} \mathrm{~S}$ in the hydrothermal fluids were uniformly high at $>10 \mathrm{~J} / \mathrm{kg}$ mixed fluid (Figure 6A). Even in ultramafic rock-associated hydrothermal systems with relatively low $\mathrm{H}_{2} \mathrm{~S}$ concentrations, the metabolic energy of sulfur oxidation $\left(\mathrm{H}_{2} \mathrm{~S}\right.$ oxidation) was nearly identical to that in other types of hydrothermal systems, some of which had 2 orders of magnitude higher $\mathrm{H}_{2} \mathrm{~S}$ concentrations (Figure 6A). This uniformity is attributed to the relatively high concentrations of $\mathrm{H}_{2} \mathrm{~S}$ (mostly $>1 \mathrm{mmol} / \mathrm{kg}$ ) present in hydrothermal fluids in all of the hydrothermal systems. As a result, the amount of $\mathrm{H}_{2} \mathrm{~S}$ always exceeded the $\mathrm{O}_{2}$ concentration throughout the habitable temperature range in the mixing zones, except at very low temperatures (several degrees Celsius). The potential energy yield of sulfur-oxidizing chemolithotrophy is therefore solely controlled by the dissolved $\mathrm{O}_{2}$ concentration in the seawater (which is globally similar in all deep-sea water). Thus, concentrations of $\mathrm{H}_{2} \mathrm{~S}$ in end-member hydrothermal fluids may not significantly affect the abundance and composition of sulfur oxidizers.

The exception is in hydrothermal plumes, where much higher seawater mixing ratios $(>1000)$ and low temperatures (up to several degrees Celsius) are found. In hydrothermal plume environments, the concentration of $\mathrm{H}_{2} \mathrm{~S}$ in the source hydrothermal fluid, rather than the seawater-dissolved $\mathrm{O}_{2}$, becomes the limiting factor for sulfur-oxidizing chemolithotrophic metabolism.

\section{Hydrogen $\left(\mathrm{H}_{2}\right)$}

In contrast to $\mathrm{H}_{2} \mathrm{~S}$, variations in the $\mathrm{H}_{2}$ concentration directly affected the potential energy for the chemolithotrophic microbial population, not only for aerobic $\mathrm{H}_{2}$ oxidation but also for most anaerobic energy metabolisms 


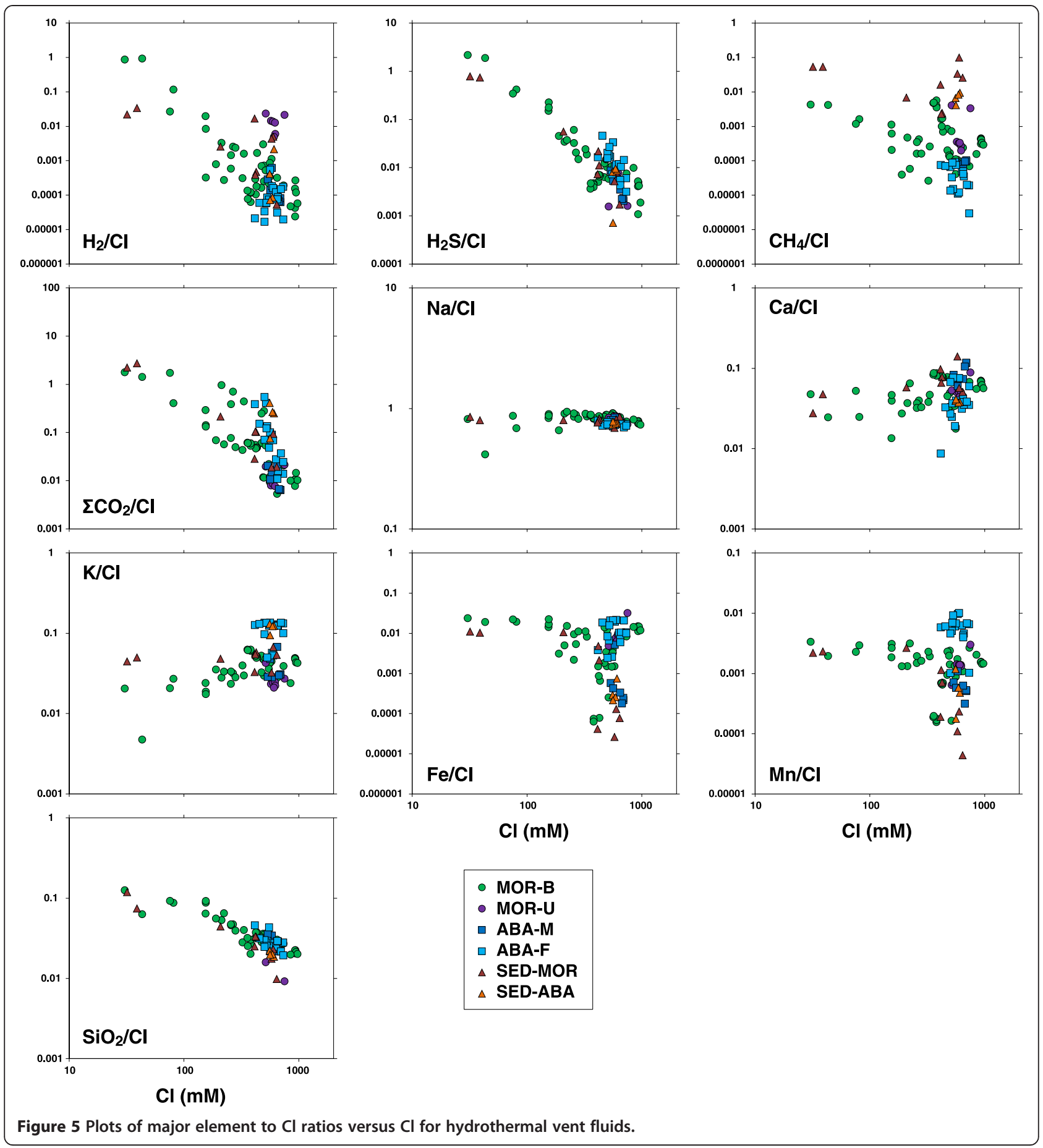

other than anaerobic methane oxidation. This feature is partially attributed to the wide range of $\mathrm{H}_{2}$ concentrations in hydrothermal fluids. For example, typical basalt-hosted hydrothermal fluids had $\mathrm{H}_{2}$ concentrations of $<1 \mathrm{mmol} /$ $\mathrm{kg}$ (Figure 2). In contrast, ultramafic rock-hosted hydrothermal fluids had $\mathrm{H}_{2}$ concentrations 1 to 2 orders of magnitude higher, whereas hydrothermal fluids in ABA settings had $\mathrm{H}_{2}$ concentrations 1 order of magnitude lower (Figure 2). Thus, potential energy yields for aerobic and anaerobic $\mathrm{H}_{2}$-oxidizing $\left(\mathrm{H}_{2}\right.$-trophic) metabolisms were directly correlated with $\mathrm{H}_{2}$ concentrations in the end-member hydrothermal fluids (Figure 6B, C, D). For aerobic $\mathrm{H}_{2}$-oxidizing metabolism, nearly the same amount of metabolic energy was available irrespective of the $\mathrm{H}_{2}$ concentration in the end-member hydrothermal fluid (Figure 6B), when the $\mathrm{H}_{2}$ concentration exceeded 


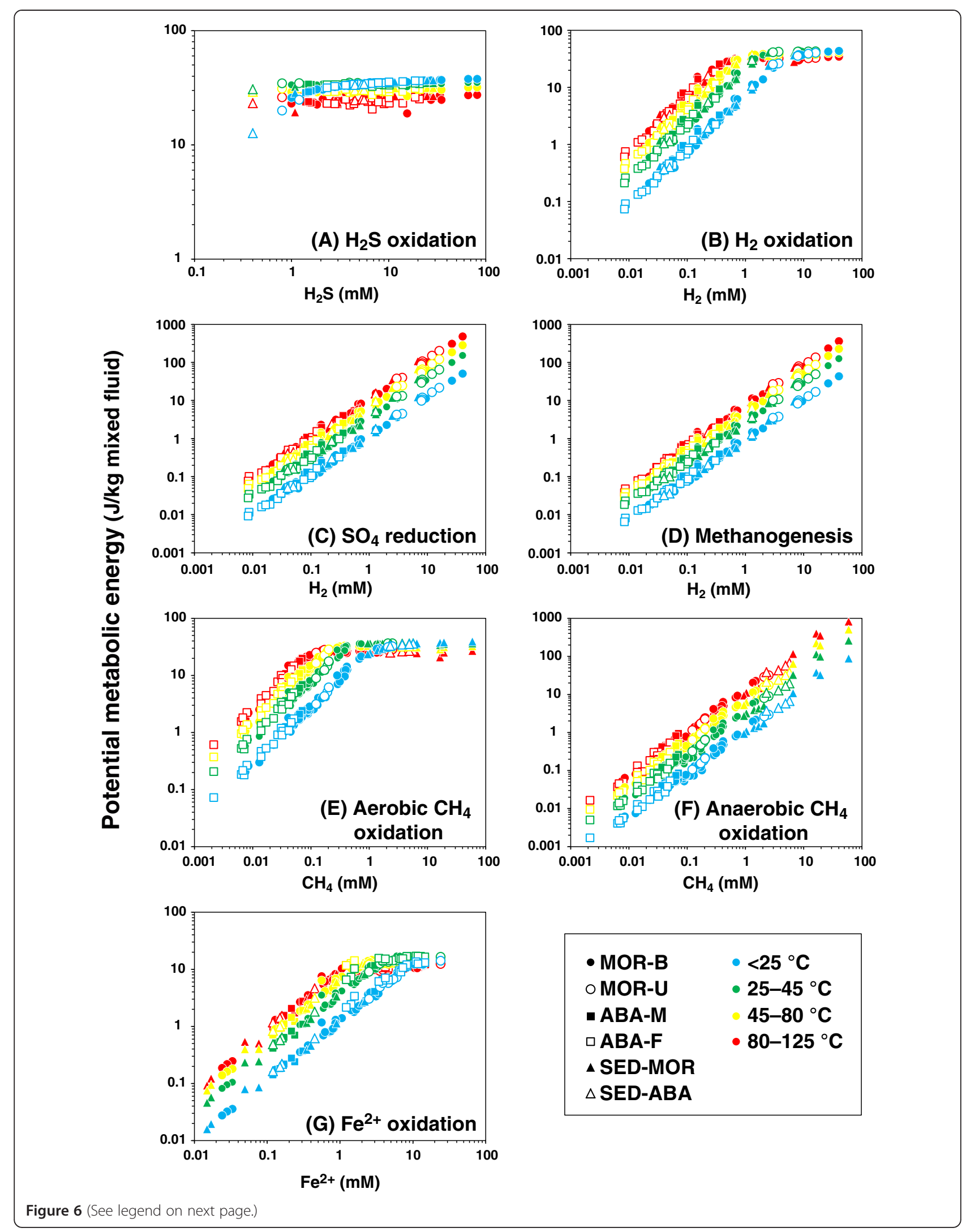


approximately $1 \mathrm{mmol} / \mathrm{kg}$ (for hyperthermophiles at relatively high temperatures) to approximately $10 \mathrm{mmol} / \mathrm{kg}$ (for psychrophiles to hyperthermophiles at all temperature ranges). As with $\mathrm{H}_{2} \mathrm{~S}$ oxidation, this occurs because seawater-dissolved $\mathrm{O}_{2}$ rather than $\mathrm{H}_{2}$ becomes the limiting factor for aerobic $\mathrm{H}_{2}$-oxidizing metabolism.

However, because most seafloor hydrothermal fluids had $\mathrm{H}_{2}$ concentrations $<1 \mathrm{mmol} / \mathrm{kg}$, except for ultramafic rock-hosted and highly vapor phase-enriched hydrothermal fluids (Figure 2), variations in the $\mathrm{H}_{2}$ concentration of the end-member hydrothermal fluid significantly affected the potential energy yields of nearly all $\mathrm{H}_{2}$-trophic chemolithotrophs (Figure 6B, C, D). This variation is expected to have a strong impact on biomass production and the compositional structure of most $\mathrm{H}_{2}-$ trophic microbial populations as well as the entire microbial community. As described above, the abundance of $\mathrm{H}_{2} \mathrm{~S}$ in hydrothermal fluids is relatively constant among most hydrothermal systems, tectonic settings, and geological conditions. In addition, $\mathrm{H}_{2} \mathrm{~S}$ is coupled only to aerobic (both $\mathrm{O}_{2}$ - and $\mathrm{NO}_{3}$-reducing) sulfuroxidizing metabolisms. In contrast, the abundance of $\mathrm{H}_{2}$ in end-member hydrothermal fluids is highly variable and constrains various aerobic and anaerobic chemolithotrophic energy metabolisms for primary production.

Although ultramafic rock-associated hydrothermal fluids are significantly enriched in $\mathrm{H}_{2}$ (Charlou et al. 2002), in several phase separation-influenced (vapor phase-abundant) hydrothermal fluids hosted by MOR-B, $\mathrm{H}_{2}$ can also be comparably enriched (Lilley et al. 2003) (Figure 2). In these hydrothermal systems, therefore, the energy yield of $\mathrm{H}_{2}$-trophic metabolisms was similar to that in ultramafic rock-hosted hydrothermal systems (Figure 6B, C, D). However, the abundant availability of $\mathrm{H}_{2}$ (as well as other gaseous species) induced by phase separation in MOR-B-hosted hydrothermal fluids is generally transient and lasts several weeks to several months (Lilley et al. 2003). Thus, the effect of temporal enrichment of hydrothermal fluid $\mathrm{H}_{2}$ on biomass production and compositional structure of the entire microbial community is likely transient and minor.

\section{Methane $\left(\mathrm{CH}_{4}\right)$}

The $\mathrm{CH}_{4}$ concentration in seafloor hydrothermal fluids was also variable, ranging from the nanomole per kilogram level in ABA hydrothermal fluids to the millimole per kilogram level in SED and ultramafic rockhosted fluids. Variations in the $\mathrm{CH}_{4}$ concentration in hydrothermal fluids could affect both aerobic and anaerobic methane oxidizers (Figure 6E, F).

The potential metabolic energy from anaerobic $\mathrm{CH}_{4}$ oxidation (methanotrophy) was directly correlated with the $\mathrm{CH}_{4}$ concentration in the hydrothermal fluid (Figure 6F), suggesting that the anaerobic methanotrophic population is likely affected by $\mathrm{CH}_{4}$ concentrations in endmember hydrothermal fluids. This is attributable to the large amount of $\mathrm{SO}_{4}{ }^{2-}$ in seawater; these high levels of $\mathrm{SO}_{4}{ }^{2-}$ are always present in seawater-hydrothermal fluid mixing zones in all habitable temperature ranges. For aerobic $\mathrm{CH}_{4}$ oxidation reactions, the potential energy yield was also affected by the $\mathrm{CH}_{4}$ concentration in end-member hydrothermal fluids, except for hydrothermal fluids with high $\mathrm{CH}_{4}$ concentrations $(>0.2 \mathrm{mmol} / \mathrm{kg}$ for hyperthermophiles to $>2 \mathrm{mmol} / \mathrm{kg}$ for psychrophiles) (Figure 6E).

\section{Iron $(\mathrm{Fe})$}

Variation in the $\mathrm{Fe}^{2+}$ concentration of the hydrothermal fluids was also large, from the nanomole per kilogram level to the millimole per kilogram level (comparable to the ranges for $\mathrm{H}_{2}$ and $\mathrm{CH}_{4}$ concentrations). This variation in the $\mathrm{Fe}^{2+}$ concentration of the hydrothermal fluids could affect aerobic iron-oxidizing chemolithotrophy. The potential energy yield from the aerobic Fe oxidation reaction was well correlated with the $\mathrm{Fe}^{2+}$ concentration in the hydrothermal fluid (Figure 6G). However, for highly $\mathrm{Fe}^{2+}$-enriched hydrothermal fluids ( $>0.2 \mathrm{mmol} / \mathrm{kg}$ for hyperthermophiles to $>2 \mathrm{mmol} / \mathrm{kg}$ for psychrophiles), the amount of available metabolic energy was saturated with respect to the $\mathrm{Fe}^{2+}$ concentration in the end-member hydrothermal fluid (Figure 6G). The metabolic energy yield potentially obtained from aerobic oxidation of $1 \mathrm{~mol}$ of $\mathrm{Fe}^{2+}$ was several times smaller than that from aerobic oxidation of $1 \mathrm{~mol}$ of $\mathrm{H}_{2} \mathrm{~S}, \mathrm{H}_{2}$, or $\mathrm{CH}_{4}$ (Figure 6). This may affect the relative abundance of aerobic Fe-oxidizer populations in deepsea hydrothermal vent ecosystems.

In contrast to aerobic Fe-oxidizing chemolithotrophy, there was an essentially negligible energy yield predicted for anaerobic $\mathrm{Fe}^{3+}$ reduction using $\mathrm{H}_{2}$ or $\mathrm{CH}_{4}$ for all 
types of deep-sea hydrothermal fluids and systems. This is attributed to an extremely low concentration of $\mathrm{Fe}^{3+}$ in both seawater and hydrothermal fluids.

\section{Effect of the geological setting of the hydrothermal system on the bioavailable energy yield}

In the MOR-B and all ABA settings (comprising most deep-sea hydrothermal systems), almost all potentially bioavailable energy can be obtained from aerobic metabolism (Figure 7). The end-member hydrothermal fluids in these settings contain only small amounts of $\mathrm{H}_{2}$ and $\mathrm{CH}_{4}$ (other than highly vapor-enriched hydrothermal fluids). The most energetically favorable chemolithotrophic metabolism was aerobic sulfur oxidation (Figure 8A). Thus, aerobic sulfur oxidizers are the chemolithoautotrophic population most likely to sustain primary production in these deep-sea hydrothermal vent ecosystems.

In the MOR-B and ABA-M settings, aerobic oxidation of $\mathrm{H}_{2}$ and $\mathrm{CH}_{4}$ were the second most available metabolic reactions, particularly at higher temperatures (lower mixing ratios). On the other hand, in the ABA-F setting, aerobic $\mathrm{Fe}^{2+}$ oxidation was the second most favorable chemolithotrophic metabolism (Figure 8A). These differences are directly related to the different chemical compositions of the end-member hydrothermal fluids (e.g., $\mathrm{H}_{2}, \mathrm{CH}_{4}$, and $\mathrm{Fe}^{2+}$ concentrations) in these settings, ultimately derived from the oxidation state of the magmas and/or volatile (particularly $\mathrm{SO}_{2}$ ) inputs into the hydrothermal fluids. Relatively little energy was predicted to be available from anaerobic chemolithotrophic metabolisms for these settings, except for temporally and spatially limited habitats induced by phase separation of hydrothermal fluids (Figure 8B).

In the MOR-U and SED settings, the potential energy from aerobic oxidation of $\mathrm{H}_{2}$ or $\mathrm{CH}_{4}$ exceeded that from aerobic sulfur oxidation at higher temperatures (lower mixing ratios) (Figure 8A). More importantly, in these settings, considerable energy for primary production can be obtained from anaerobic chemolithotrophic metabolisms and populations (Figure 8B). Particularly in hightemperature habitats, anaerobic chemolithotrophs are expected to play a prominent role as primary producers (Figure 8A, B). This represents a marked difference in potential chemolithotrophic microbial communities between the MOR-U and SED settings and the more common MOR-B and ABA settings.

In the MOR-U setting, because of the high $\mathrm{H}_{2}$ concentrations in end-member fluids, both aerobic and anaerobic $\mathrm{H}_{2}$-trophic population reducers were energetically dominant primary producers (Figure $8 \mathrm{~A}, \mathrm{~B}$ ). In addition, the total potentially bioavailable energy yields in the mixing zones were greater in the MOR-U setting than in the typical MOR-B and ABA settings (Figure 8A, B). Thus, the MOR-U deep-sea hydrothermal environments may supply more abundant and diverse energy sources for biological production.

In the SED setting, aerobic methanotrophy could be competitive with aerobic sulfur oxidation in all temperature ranges (Figure 8A). Interestingly, among all possible chemolithotrophic metabolisms, anaerobic (sulfate-reducing) methanotrophy was by far the most favorable energy-generating metabolism, particularly in high-temperature habitats (Figure $8 \mathrm{~B}$ ). The total amount of potentially bioavailable energy yield in the mixing zones of habitats in the SED setting was also greater than in the typical MOR-B and ABA settings.

\section{Comparison of existing chemolithotrophic microbial} communities with the results of thermodynamic modeling

Above, we have provided the theoretical basis for relationships between the geological environments of hydrothermal activity (e.g., tectonic settings, basement-rock geochemistry, abundance of sediments, magmatic volatile input, and phase separation related to subseafloor hydrothermal processes), physical and chemical variations in hydrothermal fluids, and the compositional diversity of potentially bioavailable energy for various vent-endemic chemolithotrophic metabolisms estimated using thermodynamic models. We have shown that the abundance and composition of chemolithotrophic energy metabolisms in hydrothermal vent biological communities is directly constrained by the physical and chemical characteristics of the hydrothermal mixing zones of habitats, which are subject to the physical and chemical properties of endmember hydrothermal fluids. Furthermore, the physical and chemical characteristics of the end-member hydrothermal fluids are substantially controlled by the geological settings that host the hydrothermal systems. Thus, it seems likely that the abundance and composition of chemolithotrophic energy metabolisms in microbial communities located in a given deep-sea hydrothermal system could be systematized in terms of geological backgrounds based on the results of the thermodynamic models.

In typical mixing zones in deep-sea hydrothermal habitats, chemolithotrophic microbial communities consist of organisms with three typical lifestyles: surface-attached or biofilm-forming free-living entities, planktonic free-living entities, and symbiotic entities. Here, we discuss potential patterns in chemolithotrophic microbial community development delineated by recent microbiological investigations (biogeochemical, ecological, and molecular approaches) for representative hydrothermal mixing zones of habitats in which the predominant organisms have different lifestyles.

\section{Hydrothermal plumes}

Hydrothermal plumes are typical of mixing zone habitats that host planktonic free-living microbial communities 


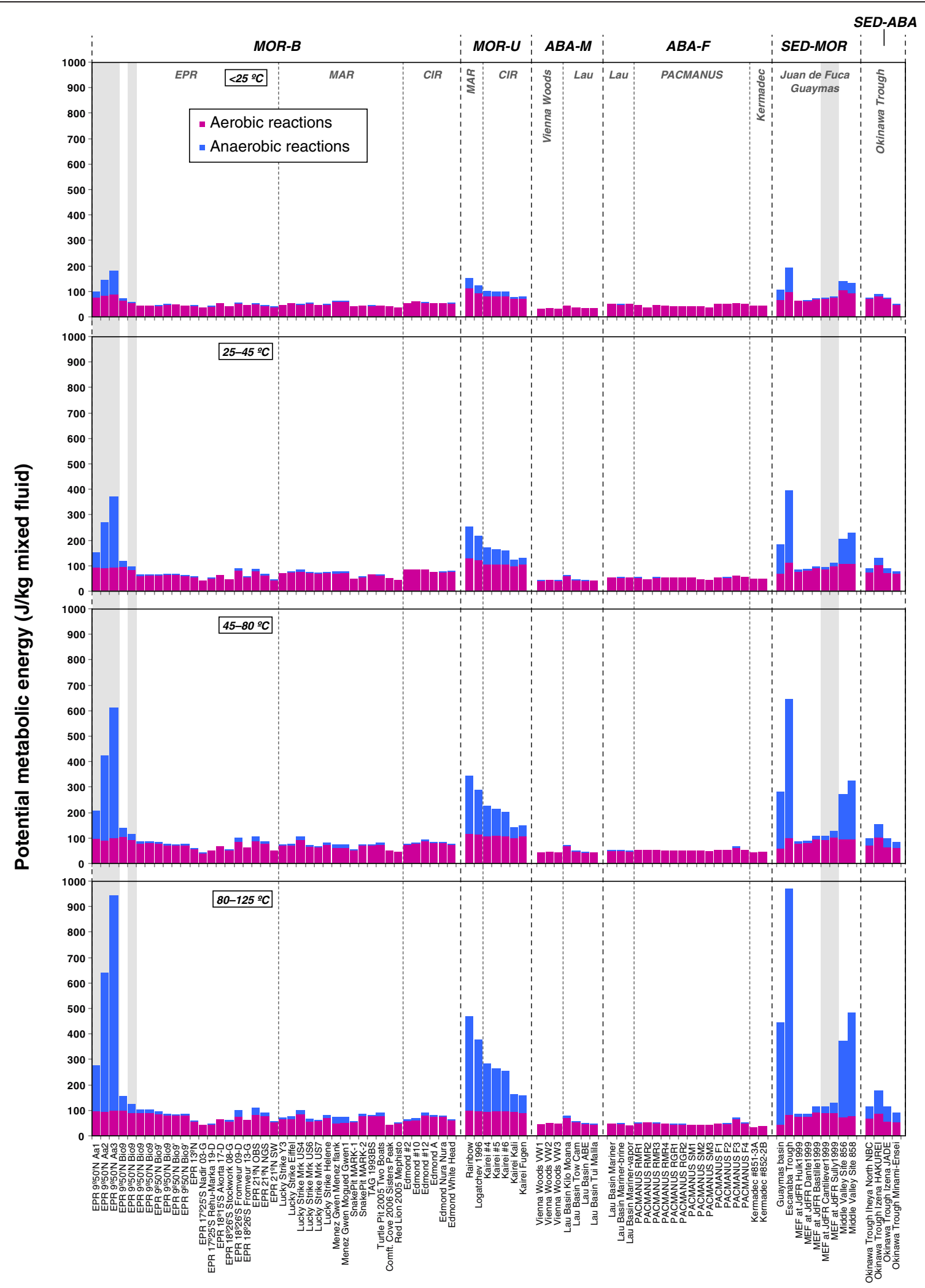

Figure 7 Metabolic energies available from the aerobic and anaerobic reactions shown in Table 1. Calculations were performed for all the 89 hydrothermal vent sites in MOR-B, MOR-U, AMA-M, ABA-F, SED-MOR, and SED-ABA settings. Shaded areas represent hydrothermal vents issuing highly vapor-rich (<100 mmol/kg Cl) fluids. 


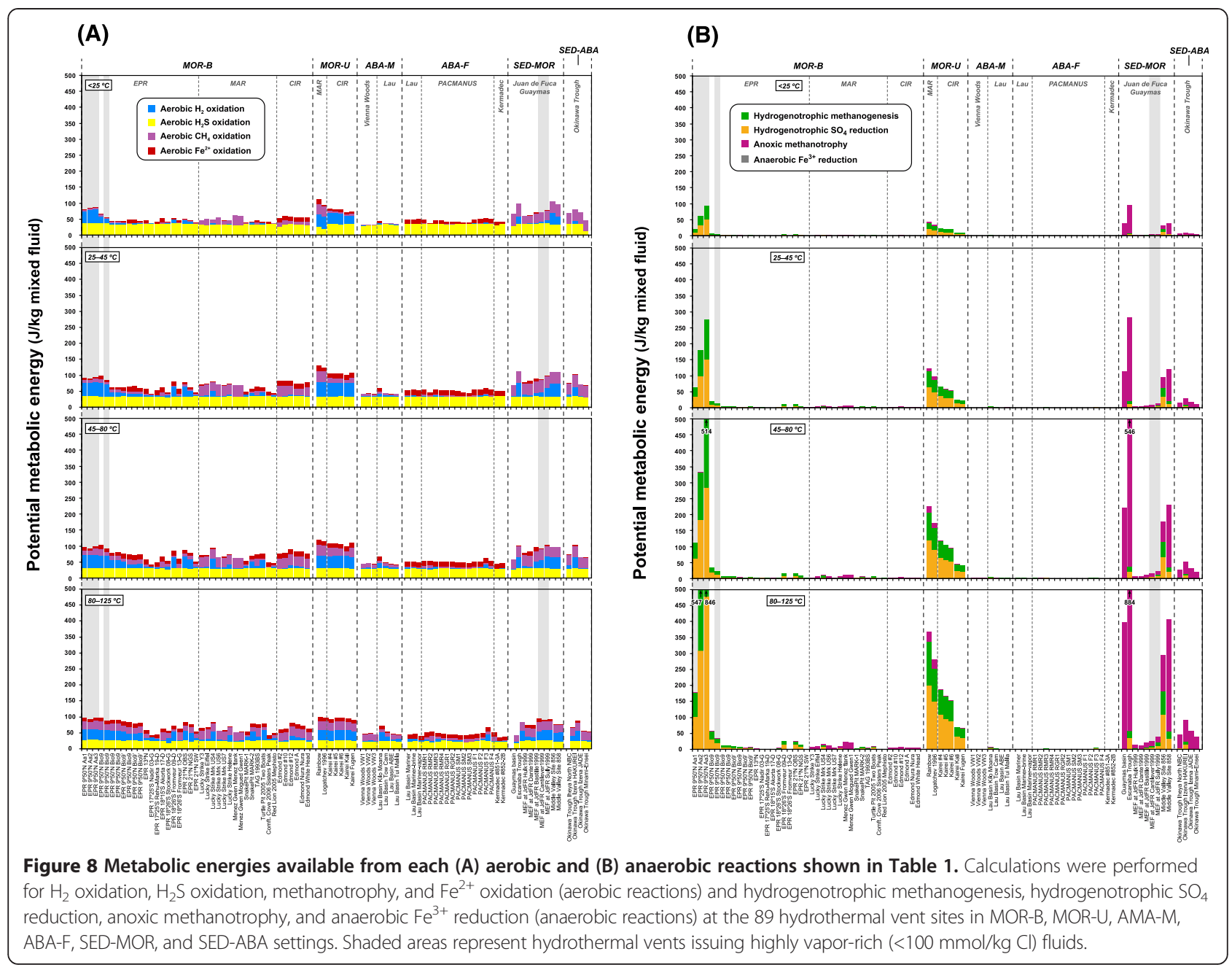

and are characterized by low temperatures and quite low mixing ratios of hydrothermal fluids $(<0.1 \%)$. In hydrothermal plumes, the SUP05 group of Gammaproteobacteria is the most abundant and geographically widespread microbial component (Sunamura et al. 2004; Dick and Tebo 2010; German et al. 2010). The deepsea vent Epsilonproteobacteria (Sunamura et al. 2004; Nakagawa et al. 2005a; German et al. 2010), methanotrophic Gammaproteobacteria (Lam et al. 2008), and ammoniaoxidizing Betaproteobacteria and Thaumarchaeota (Lam et al. 2008; Takai et al. 2004b) have been identified as other dominant microbial populations.

Although microbial communities in hydrothermal plumes have variable abundances and compositions of chemolithotrophic metabolisms, there have been few quantitative studies or functional characterizations of these communities. Thus, we still do not know much about how these microbial communities and their metabolisms respond to the varying physical and chemical states of hydrothermal plume habitats or how they are related to the geological backgrounds that produce the source hydrothermal fluids. Nevertheless, the general landscape of metabolic abundance and composition in hydrothermal plume microbial communities has been established via biogeochemical (Cowen et al. 1986; de Angelis et al. 1993; Mandernack and Tebo, 1993; Dick et al. 2009) and microbial ecology (Sunamura et al. 2004; Takai et al. 2004b; Nakagawa et al. 2005a; Lam et al. 2008; Dick and Tebo 2010; Lesniewski et al. 2012) investigations. For example, dominance of the sulfuroxidizing SUP05 group of Gammaproteobacteria and the deep-sea vent Epsilonproteobacteria is commonly observed in geographically and geologically diverse deepsea hydrothermal systems. These organisms primarily sustain themselves via aerobic sulfur oxidation; considerable populations occasionally utilize aerobic $\mathrm{H}_{2}$ oxidation for additional energy conversion if metabolically available $\mathrm{H}_{2}$ is present. In addition, much smaller but ubiquitous populations of phylogenetically diverse bacteria also utilize $\mathrm{Fe}^{2+}$ and $\mathrm{Mn}^{2+}$ oxidation for biomass production. In contrast, in hydrothermal plumes highly enriched in $\mathrm{CH}_{4}$ and $\mathrm{NH}_{4}^{+}$, particularly in SED hydrothermal systems, the 
methanotrophic Gammaproteobacteria and ammoniaoxidizing Betaproteobacteria and Thaumarchaeota dominate the microbial communities in spatially and temporally varying hydrothermal plume habitats.

An increasing number of recent observations appear consistent with our conclusions based on thermodynamic estimates of bioavailable energy yields in lowtemperature mixing zones: (1) aerobic sulfur oxidation is the most common and basic chemolithotrophic energy metabolism in global deep-sea hydrothermal systems, (2) aerobic $\mathrm{Fe}^{2+}$ and $\mathrm{Mn}^{2+}$ oxidation are less abundant but widespread metabolisms, and (3) aerobic methanotrophy and ammonia oxidizer are dominant in SED systems, respectively.

\section{Diffusing hydrothermal fluids}

Microbial communities in relatively low-temperature diffusing hydrothermal fluids have been investigated in a wide variety of geographically diverse hydrothermal systems (Huber and Holden 2008; Huber et al. 2009; Perner et al. 2011, 2013a, 2013b; Akerman et al. 2013; Campbell et al. 2013). These are mainly planktonic free-living communities under conditions in which the endmember fluids have already mixed with infiltrated seawater in relatively shallow subseafloor environments in the recharge and discharge regions of hydrothermal fluids (Bemis et al. 2012). In addition to planktonic freeliving populations, these microbial communities also include detached epilithic and biofilm-forming components entrained by the fluid flows.

Hydrothermal fluids diffusing at the seafloor would be expected to combine all growing, living, and dead populations and components within the entire subseafloor fluid flow path in the discharge. This differs from microbial communities in hydrothermal plume habitats in which most microbial populations are indigenously growing from planktonic origins in deep-sea water (Lesniewski et al. 2012). Thus, it is challenging to clearly understand the relationships between the diversity and composition of the observed microbial populations and hydrothermal fluid chemistry based on existing biological and geochemical data for diffusing fluid habitats. However, several studies have recently suggested the dominance of sulfur oxidizers in typical MOR-B settings and the presence of hydrogen oxidizers in MOR-U settings (Perner et al. 2011, 2013a; Akerman et al. 2013). These results are generally consistent with our thermodynamic predictions of relationships among microbial metabolisms and functions, hydrothermal fluid chemistry, and geological background.

On the other hand, a very recent study producing function-focused quantitative estimates, based on $\mathrm{H}_{2}$ and sulfide consumption and $\mathrm{CO}_{2}$ assimilation activities as well as metagenomic $16 \mathrm{~S}$ rRNA and functional gene analyses, has indicated that even in $\mathrm{H}_{2}$-poor hydrothermal fluids in MOR-B settings, $\mathrm{H}_{2}$ oxidation-based primary production is highly attractive despite the low $\mathrm{H}_{2}$ content (Perner et al. 2013b). This leads us to consider that low-temperature diffusing flow is the product of complex subseafloor processes (including seawaterhydrothermal fluid mixing, conductive cooling, various redox reactions, and mineral precipitation), and thus, the simple batch-mixing model employed in this study may not be able to accurately reproduce all of these processes.

Geochemical data sets for low-temperature diffusing flows remain scarce. Thus, further quantitative estimates combined with in situ or detailed chemical measurements will be needed to more accurately describe interactions among the physical and chemical processes, bioavailable energy yields from chemolithotrophic metabolisms, and community development in diffusing hydrothermal fluids.

\section{Chemosynthetic invertebrates}

Chemolithotrophic symbionts hosted by deep-sea ventendemic chemosynthetic invertebrates represent important primary producers in global deep-sea hydrothermal ecosystems. Their biomass production and functions may be constrained by the energy states of the habitats of both the symbionts and the host animals (Dubilier et al. 2008), as productivity and energy metabolism in a tight symbiotic association are strongly regulated by the interaction of the symbiont with the physiology and ecology of the host animal (Dubilier et al. 2008). There have been numerous studies of the basic relationships between the in situ physical and chemical conditions of habitats and the abundance and composition of energy metabolisms in deep-sea hydrothermal chemosynthetic symbioses (Beinart et al. 2012; Petersen et al. 2011; Suzuki et al. 2006; Watsuji et al. 2010, 2014). However, the energy conversion yield of the primary production of chemolithotrophic symbionts is likely one of the most important factors in the establishment of chemosynthetic symbioses, affecting the selection, acquisition, and breeding of specific bacterial counterparts. In particular, episymbioses and horizontally transmitted endosymbioses, in which symbionts are acquired from the proximal environments of habitats in their larval and adult stages in each generation, would be expected to be more strongly affected by the energy states of chemolithotrophic symbiont metabolisms than vertically transmitted endosymbioses.

Recently, several studies have been conducted of the relationship between the activity of chemolithotrophic symbionts and hydrothermal fluid chemistry, e.g., a series of studies on epibiotic microbial communities in the galatheid crab Shinkaia crosnieri in Okinawa Trough 
(Watsuji et al. 2010, 2012, 2014). The epibiotic microbial communities of S. crosnieri abdominal setae consist primarily of the sulfur-oxidizing Epsilonproteobacteria and Gammaproteobacteria and methanotrophic Gammaproteobacteria (Watsuji et al. 2010, 2012, 2014). These results are generally consistent with the results of our thermodynamic modeling, indicating high bioavailable energy yields from both sulfur- and $\mathrm{CH}_{4}$-oxidizing reactions at low temperatures (high seawater mixing ratios) in the Okinawa Trough (Figure 8). The abundance of epibiotic methanotrophic gammaproteobacterial populations and methanotrophic activity vary among the S. crosnieri populations recovered from different hydrothermal fields (Iheya North and Hatoma Knoll fields) (Watsuji et al. 2010). As suggested by our model calculations, these variations are likely correlated with the in situ $\mathrm{CH}_{4}$ concentrations in the S. crosnieri colonies. This may, in turn, be associated with the $\mathrm{CH}_{4}$ concentrations in the end-member hydrothermal fluids, although $\mathrm{CH}_{4}$ concentrations in the Hatoma fluids have not yet been published.

Another notable example is the dual endosymbiotic (thiotrophic and methanotrophic) populations of vent mussels living in different geological settings of deep-sea hydrothermal vent sites in the MAR and the Eastern Pacific (Petersen et al. 2011). Based on thermodynamic modeling of preferred $\mathrm{H}_{2}$-trophic energy metabolism, genetic characterization of a key enzyme gene for $\mathrm{H}_{2}$ trophic energy metabolism, and functional analyses of $\mathrm{H}_{2}$ consumption and $\mathrm{CO}_{2}$ fixation of endosymbionts in Bathymodiolus puteoserpentis in a typical MOR-U hydrothermal system (Logatchev field), Peterson et al. (2011) clearly demonstrated that the thiotrophic population in dual endosymbiosis of the Logatchev B. puteoserpentis use $\mathrm{H}_{2}$ and $\mathrm{H}_{2} \mathrm{~S}$ comparably as energy sources for primary production. This was the first reported example of chemosynthetic symbiosis sustained by an inorganic energy source $\left(\mathrm{H}_{2}\right)$ other than $\mathrm{H}_{2} \mathrm{~S}$ (reduced sulfur species) or $\mathrm{CH}_{4}$. In other words, this study first revealed that compositional variations in $\mathrm{H}_{2}, \mathrm{H}_{2} \mathrm{~S}$, and $\mathrm{CH}_{4}$ in the mixing zones of chemosynthetic macrofaunal habitats affect the patterns and functions of episymbioses and endosymbioses in chemosynthetic microbial-faunal associations. Peterson et al. (2011) also showed that the thio- and $\mathrm{H}_{2}$-trophic endosymbionts hosted by different Bathymodiolus populations living in geographically and geologically distinct hydrothermal systems of the MAR and Pacific (all $\mathrm{H}_{2}$-starved MOR-B hydrothermal systems) had much lower specific $\mathrm{H}_{2}$ consumption activities than the endosymbiotic population from the $\mathrm{H}_{2}$-abundant MOR-U hydrothermal system (Logatchev field). Although not fully quantitative, these results provide strong evidence that the metabolic activity of chemolithotrophic symbionts is controlled by hydrothermal fluid chemistry and is related to the geological background of the hydrothermal system, as suggested by our model calculations.

Recently, metagenomic and metatranscriptomic approaches have also been used to study possible biogeochemical associations with Alviniconcha (deep-sea hydrothermal-vent snail) holobionts (host/symbiont associations) that dwell in a broad region of the Eastern Lau Spreading Center (ELSC) (Beinart et al. 2012; Sanders et al. 2013). Different holobiont patterns have been found in the Alviniconcha populations obtained from the mixing zones of colonies in four different hydrothermal systems in the ELSC. The endosymbionts were classified into three groups: Sulfurimonas-type Epsilonproteobacteria, gamma1-type Gammaproteobacteria, and gamma-Lau-type Gammaproteobacteria (Beinart et al. 2012), all of which are known to be typical sulfur (and $\mathrm{H}_{2}$ ) oxidizers. The Alviniconcha holobiont and endosymbiont distributions varied from the northern to the southern region of the ELSC, which have somewhat different geological settings (Beinart et al. 2012). The ELSC has been well characterized from north to south in terms of geological properties (such as the spreading stage and rate, magmatic productivity, geochemistry, and host-rock geochemistry) (Tivey et al. 2012). Reflecting the change in geological setting, the chemical compositions of the end-member hydrothermal fluids also change from relatively reduced and $\mathrm{H}_{2-}$ and $\mathrm{H}_{2} \mathrm{~S}$-enriched (approximately $500 \mu \mathrm{M}$ and approximately $5 \mathrm{mM}$, respectively) in the north to relatively oxidized and $\mathrm{H}_{2}$ - and $\mathrm{H}_{2} \mathrm{~S}$-depleted (approximately $30 \mu \mathrm{M}$ and approximately $3 \mathrm{mM}$, respectively) in the south (Beinart et al. 2012). The endosymbiont species shift from predominantly Sulfurimonas-type Epsilonproteobacteria in the north to predominantly gamma-1-type Gammaproteobacteria and finally to both types of Gammaproteobacteria in the south (Beinart et al. 2012). Interestingly, the compositional abundance of both the endosymbiotic microbial components and the expressed key gene transcripts for various energy metabolisms vary with the regional geochemical gradient (Sanders et al. 2013). Under relatively reduced and $\mathrm{H}_{2}$ - and $\mathrm{H}_{2} \mathrm{~S}$-enriched conditions, the compositional abundance of mRNAs related to $\mathrm{H}_{2}$ - and sulfur-oxidizing metabolisms throughout the entire endosymbiont transcriptome is highly elevated (Sanders et al. 2013). The compositional abundances of the mRNAs of these energy metabolisms throughout the entire endosymbiont transcriptome are likely associated with the activities of these energy metabolisms in the endosymbiotic populations of the Alviniconcha host individuals.

Our geochemical modeling suggests that changes in the $\mathrm{H}_{2} \mathrm{~S}$ concentration from north to south in the ELSC (approximately $5 \mathrm{mM}$ to approximately $3 \mathrm{mM}$ ) should not significantly affect sulfur-oxidizing metabolisms, whereas $\mathrm{H}_{2}$-oxidizing metabolisms could be affected by 
the change in $\mathrm{H}_{2}$ concentration (approximately $500 \mu \mathrm{M}$ to approximately $30 \mu \mathrm{M}$ ) (Figure 6). Indeed, based on differences in the expression of hydrogenases between Epsilonproteobacteria and Gammaproteobacteria individuals, Sanders et al. (2013) suggested that $\mathrm{H}_{2}$ oxidation may play a larger role in the energy metabolism of holobionts with Epsilonproteobacteria. Thus, the change in $\mathrm{H}_{2}$ concentration, rather than the $\mathrm{H}_{2} \mathrm{~S}$ concentration, may account for differences in the holobiont patterns found in the Alviniconcha populations in the ELSC. Although future studies are needed to elucidate the degree to which Epsilonproteobacteria endosymbionts rely on $\mathrm{H}_{2}$ for energy production, this may be additional evidence supporting the relationship between geological constraints on hydrothermal fluid chemistry and the compositions and functions of chemosynthetic microbial symbionts in deep-sea hydrothermal environments.

\section{Chimney structures and sediments}

The compositional and functional diversity of microbial communities has been most extensively explored in deepsea vent chimney structures that host high-temperature hydrothermal fluid emissions (Nakagawa and Takai 2008; Takai and Nakamura 2010, 2011; Takai et al. 2006b). These microbial communities consist of typical epilithic (mineral surface-attached) and/or biofilm-forming populations and are sustained by the redox disequilibria formed in the chimney wall via diffusive mixing between the internal hydrothermal fluid and external seawater. Thus, the abundance and composition of chemolithotrophic energy metabolisms in the chimney microbial communities are directly controlled by the energy states of the chimney habitats, resulting in good approximations by the thermodynamic calculations of the simple batch-mixing model.

Using data for both end-member hydrothermal fluids and chimney microbial communities obtained from six deep-sea hydrothermal systems with different geological settings, Takai and Nakamura $(2010,2011)$ constructed intra-field and inter-field comparisons between the abundance and composition of chemolithotrophic energy metabolisms predicted by thermodynamic modeling and the microbial community composition determined through quantitative cultivation methods. Based on both the thermodynamic modeling and microbiological characterization, statistically significant correlations between the $\mathrm{H}_{2}$ concentration in the hydrothermal fluid or the estimated potential energy yield of $\mathrm{H}_{2}$-trophic methanogenesis and the cultivatable population size of hydrogenotrophic methanogens were found. More recently, in addition to quantitative cultivation methods, statistical phylotype compositional analyses of $16 \mathrm{~S}$ rRNA and other functional genes have also been used to demonstrate significant correlations between $\mathrm{H}_{2}$-trophic chemolithotrophy in chimney microbial communities and hydrothermal fluid $\mathrm{H}_{2}$ concentrations, particularly in MOR-U hydrothermal systems (Flores et al. 2011; Roussel et al. 2011). Our geochemical model provides consistent explanations for the results of these studies. Specifically, the energy yields of anaerobic (and aerobic, in most cases) $\mathrm{H}_{2}$-trophic reactions were well correlated with the $\mathrm{H}_{2}$ concentrations of hydrothermal fluids (Figure 6). In addition, thermophilic $\mathrm{H}_{2}$-trophic methanogens and sulfate/sulfur reducers are predominantly found in $\mathrm{H}_{2}$ enriched deep-sea hydrothermal systems in the MOR-U setting (Figure 8). It is thus very likely that serpentinizationdriven $\mathrm{H}_{2}$ enrichment in hydrothermal fluids is an important geochemical factor that directly controls the thermodynamic energy potential, biomass, and productivity of $\mathrm{H}_{2}$-trophic chemolithotrophs.

Similar to the apparent relationship between $\mathrm{H}_{2}$ concentrations in hydrothermal fluids and the abundance of $\mathrm{H}_{2}$-trophic chemolithotroph populations, our thermodynamic calculations also identified a possible relationship between $\mathrm{CH}_{4}$ enrichment and the abundance of anaerobic methanotroph populations (particularly thermophilic methanotrophic sulfate reducers) in SED hydrothermal systems (Figure 8). In low-temperature habitats (e.g., hydrothermal plumes, diffusing fluids, and chemosynthetic animal symbioses), many molecular signals and metabolic activities of aerobic methanotrophy have been observed. However, the existence of anaerobic thermophilic methanotrophic sulfate reducers has been inferred only from lipid biomarker signals (Schouten et al. 2003). Recently, thermophilic anoxic $\mathrm{CH}_{4}$-oxidizing $\mathrm{SO}_{4}$-reducing activities have been directly verified at up to $70^{\circ} \mathrm{C}$ in the sediments of the Guaymas Basin hydrothermal field (Holler et al. 2011). In addition, possible microbial components of thermophilic anaerobic methane oxidizers, consortia of ANME-1a Archaea and HotSeep-1 cluster Deltaproteobacteria, have been identified via FISH analysis (Holler et al. 2011). Similar phylotypes of potentially thermophilic ANME-1a Archaea have also been found in hydrothermal sediments and diffusing fluids of SED hydrothermal systems such as the Axial Seamount and Endeavour Segment fields in the Juan de Fuca Ridge and the Yonaguni Knoll IV field in the Okinawa Trough (Nunoura et al. 2010; Merkel et al. 2013). Because these phylotypes of thermophilic anaerobic methanotrophic Archaea remain resistant to cultivation, quantitative cultivation methods are not feasible. However, other quantitative techniques targeting 16S rRNA and functional gene transcripts together with direct metabolic activity measurements are now available (e.g., Beal et al. 2009; Watsuji et al. 2012, 2014). Such quantitative estimates will provide multiple lines of evidence for the relationship between $\mathrm{CH}_{4}$ enrichment in SED hydrothermal systems and the abundance of thermophilic methanotrophic sulfate reducers in mixing zone habitats. 
Takai and Nakamura (2010) have also noted that phase separation has a considerable impact on intra-field variations in hydrothermal fluid chemistry. In microbiological studies of the Iheya North field in the middle Okinawa Trough and the Mariner field in the Lau Basin, increased populations of anaerobic and aerobic $\mathrm{H}_{2}$-trophic chemolithotrophs (e.g., Methanococcales and Aquificales) were observed, potentially due to phase separation of hydrothermal fluids (Nakagawa et al. 2005b; Takai et al. 2008). However, in studies of the Yonaguni Knoll IV field in the Southern Okinawa Trough, $\mathrm{H}_{2}$-trophic (and thiotrophic) chemolithotrophs (e.g., Methanococcales, Desulfurococcales, Nautiliaceae, and Thioreductoraceae) were the dominant microbial components in both vapor- and brine-rich hydrothermal fluids (Nunoura and Takai 2009). Although $\mathrm{H}_{2} \mathrm{~S}$ concentration data for the Yonaguni Knoll IV fluid have not yet been reported, our geochemical model calculations indicate that if the $\mathrm{H}_{2}$ concentrations of the end-member hydrothermal fluids were well below approximately $1 \mathrm{mmol} / \mathrm{kg}$, the metabolic energy available from both aerobic and anaerobic $\mathrm{H}_{2}$-trophic reactions would be directly correlated with the $\mathrm{H}_{2}$ concentration of the fluids (Figure 6). The $\mathrm{H}_{2}$ concentrations in the vapor- and brine-rich hydrothermal fluids venting at the Iheya North field ( 0.045 and $0.096 \mathrm{mmol} / \mathrm{kg}$, respectively) and the Mariner field ( 0.012 and $0.13 \mathrm{mmol} / \mathrm{kg}$, respectively) are well below approximately $1 \mathrm{mmol} / \mathrm{kg}$ and thus, phase separationinduced $\mathrm{H}_{2}$ variations may directly affect the available energy yields from aerobic and anaerobic $\mathrm{H}_{2}$-trophic reactions. In contrast, the $\mathrm{H}_{2}$ concentrations in the fluids at the Yonaguni Knoll IV field ( 0.8 to $3.6 \mathrm{mmol} / \mathrm{kg}$ ) are mostly above approximately $1 \mathrm{mmol} / \mathrm{kg}$, resulting in saturation of the metabolic energy available from aerobic hydrogenotrophic reactions, particularly at higher temperatures (Figure 6). In addition, the bioavailable energy yield from hyperthermophilic anaerobic reactions is nearly comparable to that from aerobic thiotrophic reactions, even in brine-rich hydrothermal fluids (Figure 6). This may explain why there are no major differences in abundance or composition of microbial communities between the vapor- and brine-rich hydrothermal fluids in the Yonaguni Knoll IV field (Nunoura and Takai, 2009).

\section{Conclusions}

We have provided an overview of variations in the geology, geochemistry, microbial energy metabolisms, and community development associated with global deep-sea hydrothermal systems. Relationships among the geological backgrounds of hydrothermal activities (e.g., tectonic settings, basement rock geochemistry, abundance of sediments, magmatic volatile inputs, and phase separation related to subseafloor hydrothermal processes), physical and chemical variations in hydrothermal fluids, and compositional diversity of potentially bioavailable energy for various vent-endemic chemolithotrophic metabolisms have been elucidated through thermodynamic modeling of redox states in hydrothermal mixing zone habitats. In addition, these relationships have been empirically substantiated by recent multidisciplinary biogeochemical and microbiological studies of existing microbial communities and their metabolic functions in representative deep-sea hydrothermal systems in different geographic locations and geological settings.

However, thermodynamic estimates of potential energy for possible chemolithotrophic metabolisms are based on certain simplifications, particularly with respect to quantitative representations of mixing of source hydrothermal fluids and seawater and the kinetic effects of abiotic reactions, cellular uptake and excretion of energy sources, and enzymatic functions on energy metabolism. These shortcomings may result in differences between the theoretical predictions and actual configurations and patterns in some cases. To characterize the in situ physical and chemical characteristics of hydrothermal mixing zone habitats at high spatial and temporal resolution, several electrochemical sensors have been developed and applied to various habitats such as diffusing hydrothermal fluids and chemosynthetic animal colonies. However, these sensors have some technical challenges, including multiple chemical interferences, relatively narrow dynamic ranges, and the need for in situ calibration (Luther et al. 2012). A deep-sea in situ membrane inlet mass spectrometry (MIMS) method has also been developed and used for in situ measurement of volatile and time-sensitive chemical species (Wankel et al. 2010). These newly developed in situ measurement tools will enable more precise estimates of the energy states of habitats of chemolithotrophic microbial communities. Improvement and development of biogeochemical and microbiological characterization techniques are also necessary to understand the functional and metabolic abundance and composition of microbial communities in deep-sea hydrothermal environments. It is a significant challenge to quantify the biomass, productivity, and functions of dominant microbial components in deep-sea vents. Comprehensive characterizations of in situ mRNA assemblages using such tools as GeoChip technology (Wang et al. 2009) and the metatranscriptomic approach (Dahle et al. 2013) will likely prove more objective, quantitative, and effective than employing elaborate quantitative cultivations using numerous media for intra-field and inter-field comparisons of microbial communities and their functions. Successfully overcoming these challenges is essential for clarifying the relationships between geology, geochemistry, microbial energy metabolisms, and community development associated with global deep-sea hydrothermal activities. 


\section{Additional file}

Additional file 1: Chemical compositions of end-member hydrothermal fluids and seawater used in this study. Data are from 89 hydrothermal vent sites in MOR-B, MOR-U, AMA-M, ABA-F, SED-MOR, and SED-ABA settings.

\section{Abbreviations}

ABA: arc-backarc; ABA-F: felsic rock-hosted hydrothermal system in an arc-backarc setting; ABA-M: mafic rock-hosted hydrothermal system in an arc-backarc setting; MOR: mid-ocean ridge; MOR-B: basalt-hosted hydrothermal system in a mid-ocean ridge setting; MOR-U: ultramafic rock-hosted hydrothermal system in a mid-ocean ridge setting; SED: sediment-associated; SED-ABA: sediment-associated hydrothermal system in an arc-backarc setting; SED-MOR: sediment-associated hydrothermal system in a mid-ocean ridge setting.

\section{Competing interests}

The authors declare that they have no competing interests.

\section{Authors' contributions}

Both KN and KT proposed the topic, conceived of and designed the study, compiled and processed the data, and wrote the paper. Both authors read and approved the final manuscript.

\section{Acknowledgements}

We would like to thank the two anonymous reviewers for their constructive and helpful comments, which have significantly improved the manuscript. This research was financially supported by the Ministry of Education, Culture, Science, and Technology (MEXT) of Japan through the special coordination fund Project TAIGA: Trans-crustal Advection and In situ Biogeochemical Processes of Global Subseafloor Aquifer.

\section{Author details}

${ }^{1}$ Precambrian Ecosystem Laboratory (PEL), Japan Agency for Marine-Earth Science and Technology (JAMSTEC), 2-15 Natsushima-cho, Yokosuka, Kanagawa 237-0061, Japan. ${ }^{2}$ Current address: Department of Systems Innovation, School of Engineering, The University of Tokyo, 7-3-1 Hongo, Bunkyo-ku, Tokyo 113-8656, Japan. ${ }^{3}$ Subsurface Geobiology Advanced Research (SUGAR) Project, Japan Agency for Marine-Earth Science and Technology (JAMSTEC), 2-15 Natsushima-cho, Yokosuka, Kanagawa 237-0061, Japan.

\section{Received: 8 November 2013 Accepted: 15 March 2014} Published: 22 April 2014

\section{References}

Akerman NH, Butterfield DA, Huber JA (2013) Phylogenetic diversity and functional gene patterns of sulfur-oxidizing subseafloor Epsilonproteobacteria in diffuse hydrothermal vent fluids. Front Microbiol 4. doi:10.3389/fmicb.2013.00185

Allen DE, Seyfried WE, Jr (2003) Compositional controls on vent fluids from ultramafic-hosted hydrothermal systems at mid-ocean ridges: an experimental study at $400^{\circ} \mathrm{C} 500$ bars. Gechim Cosmochim Acta 67:1531-1542

Alt JC, Shanks WC (1998) Sulfur in serpentinized oceanic peridotites: serpentinization processes and microbial sulfate reduction. J Geophys Res 103:9917-9929

Amend JP, McCollom TM, Hentscher M, Bach W (2011) Catabolic and anabolic energy for chemolithoautotrophs in deep-sea hydrothermal systems hosted in different rock types. Gechim Cosmochim Acta 75:5736-5748

Beal EJ, House CH, Orphan VJ (2009) Manganese- and iron-dependent marine methane oxidation. Science 325:184-187

Beinart RA, Sanders JG, Faure B, Sylva SP, Lee RW, Becker EL, Gartman A, Luther GW III, Seewald JS, Fisher CR, Girguis PR (2012) Evidence for the role of endosymbionts in regional-scale habitat partitioning by hydrothermal vent symbioses. Proc Natl Acad Sci U S A 109:E3241-E3250

Bemis K, Lowell RP, Farough A (2012) Diffuse flow on and around hydrothermal vents at mid-ocean ridges. Oceanography 25:182-191

Berndt ME, Allen DE, Seyfried WE, Jr (1996) Reduction of $\mathrm{CO}_{2}$ during serpentinization of olivine at $300^{\circ} \mathrm{C}$ and 500 bar. Geology $24: 351-354$
Bischoff JL, Dickson FW (1975) Seawater-basalt interaction at $200^{\circ} \mathrm{C}$ and 500 bars implications for origin of seafloor heavy-metal deposits and regulations of seawater chemistry. Earth Planet Sci Lett 25:385-397

Bischoff JL, Seyfried WE, Jr (1978) Hydrothermal chemistry of seawater from $25^{\circ}$ to $350^{\circ} \mathrm{C}$. Am J Sci $278: 838-860$

Bischoff JL, Pitzer KS (1989) Liquid-vapor relations for the system $\mathrm{NaCl}-\mathrm{H}_{2} \mathrm{O}$ summary of the P-T-x surface from 300 to $500^{\circ} \mathrm{C}$. Am J Sci 289:217-248

Bowers TS, Taylor HP, Jr (1985) An integrated chemical and stable isotope model of the origin of mid-ocean ridge hot spring systems. J Geophys Res 90:12583-12606

Bowers TS, Campbell AC, Measures Cl, Spivack AJ, Khadem M, Edmond JM (1988) Chemical controls on the composition of vent fluids at $13^{\circ}-11^{\circ} \mathrm{N}$ and $21^{\circ} \mathrm{N}$ East Pacific Rise. J Geophys Res 93:4522-4536

Butterfield DA, McDuff RE, Mottl MJ, Lilley MD, Lupton JE, Massoth GJ (1994) Gradients in the composition of hydrothermal fluids from the Endeavour Ridge vent field: phase separation and brine loss. J Geophys Res 99:9561-9583

Butterfield DA, Seyfried WE Jr, Lilley MD (2003) Composition and evolution of hydrothermal fluids. In: Halbach PE, Tunnicliffe V, Hein JR (ed) Energy and Mass Transfer in Marine Hydrothermal Systems. Dahlem University Press, Berlin

Campbell AC, Palmer MR, Klinkhammer GP, Bowers TS, Edmond JM, Lawrence JR, Casey JF, Thompson G, Humphris S, Rona P, Karson JA (1988) Chemistry of hot springs on the Mid-Atlantic Ridge. Nature 335:514-519

Campbell BJ, Polson SW, Allen LZ, Williamson SJ, Lee CK, Wommack KE, Cary SC (2013) Diffuse flow environments within basalt- and sediment-based hydrothermal vent ecosystems harbor specialized microbial communities. Front Microbiol 4. doi:10.3389/fmicb201300182

Charlou JL, Fouquet Y, Bougauit H, Donval JP, Etoubleau J, Jean-Baptiste P, Dapoigny A, Appriou P, Rona PA (1998) Intense $\mathrm{CH}_{4}$ plumes generated by serpentinization of ultra-mafic rocks at the intersection of the $15^{\circ} 20^{\prime} \mathrm{N}$ fracture zone and the Mid-Atlantic Ridge. Geochim Cosmochim Acta 62:2323-2333

Charlou JL, Donval JP, Jean-Baptiste P, Radford-Knoery J, Fouquet Y, Dapoigny A, Stievenard M (2000) Compared geochemical signatures and the evolution of Menez Gwen $\left(37^{\circ} 50^{\prime} \mathrm{N}\right)$ and Lucky Strike $\left(37^{\circ} 17^{\prime} \mathrm{N}\right)$ hydrothermal fluids south of the Azores Triple Junction on the Mid-Atlantic Ridge. Chem Geol 171:49-75

Charlou JL, Donval JP, Fouquet Y, Jean-Baptiste P, Holm N (2002) Geochemistry of high $\mathrm{H}_{2}$ and $\mathrm{CH}_{4}$ vent fluids issuing from ultramafic rocks at the rainbow hydrothermal field (36¹4'M MAR). Chem Geol 191:345-359

Cowen JP, Massoth GJ, Baker ET (1986) Bacterial scavenging of Mn and Fe in a mid- to far-field hydrothermal particle plume. Nature 322:169-171

Dahle H, Roalkvam I, Thorseth $\mathbb{H}$, Pedersen RB, Steen $\mathbb{H}$ (2013) The versatile in situ gene expression of an Epsilonproteobacteria-dominated biofilm from a hydrothermal chimney. Environ Microbiol Repts 5:282-290

de Angelis MA, Lilley MD, Olson EJ, Baross JA (1993) Methane oxidation in deep-sea hydrothermal plumes of the endeavour segment of the Juan de Fuca Ridge. Deep-Sea Res I 40:1169-1186

Dick GJ, Tebo BM (2010) Microbial diversity and biogeochemistry of the Guaymas Basin deep-sea hydrothermal plume. Environ Microbiol 12:1334-1347

Dick GJ, Clement BG, Fodrie FJ, Webb SM, Bargar JR, Tebo BM (2009) Enzymatic microbial Mn(II) oxidation and Mn biooxide production in the Guaymas Basin hydrothermal plume. Geochim Cosmochim Acta 73:6517-6530

Ding K, Seyfried WE, Jr (1992) Determination of Fe-Cl complexing in the low pressure supercritical region $(\mathrm{NaCl})$ Fe solubility constraints on the $\mathrm{pH}$ of subseafloor hydrothermal fluids. Geochim Cosmochim Acta 59:4769-4773

Ding K, Seyfried WE Jr, Tivey MK, Von Damm KL, Bradley AM, Zhang Z (2005) In situ $\mathrm{pH}$ measurement of hydrothermal fluids at mid-ocean ridges. Earth Planet Sci Lett 237:167-174

Dubilier N, Bergin C, Lott C (2008) Symbiotic diversity in marine animals: the art of harnessing chemosynthesis. Nat Rev Microbiol 6:725-740

Elderfield H, Schults A (1996) Mid-ocean ridge hydrothermal fluxes and the chemical composition of the ocean. Ann Rev Earth Planet Sci 24:191-224

Embley RW, Baker ET, Butterfield DA, Chadwick WW Jr, Lupton JE, Resing JA, de Ronde CEJ, Nakamura K, Tunnicliffe V, Dower JF, Merle SG (2007) Exploring the submarine ring of fire Mariana Arc-Western Pacific. Oceanography 20:68-79

Fisher RV, Schmincke H-U (1984) Pyroclastic Rocks. Springer, Berlin

Flores GE, Campbell JH, Kirshtein JD, Meneghin J, Podar M, Steinberg JI, Seewald JS, Tivey MK, Voytek MA, Yang ZK, Reysenbach AL (2011) Microbial community structure of hydrothermal deposits from geochemically different vent fields along the Mid-Atlantic Ridge. Environ Microbiol 13:2158-2171

Foustoukos DI, Seyfried WE, Jr (2007) Fluid phase separation processes in submarine hydrothermal systems. Rev Mineral Geochem 65:213-239

Frost RB (1985) On the stability of sulfides oxides and native metals in serpentinite. J Petrol 26:31-63 
Früh-Green GL, Connolly JA, Plas A, Kelley DS, Grobety B (2004) Serpentinization of oceanic peridotites: implications for geochemical cycles and biological activity. In: Wilcock WS, DeLong EF, Kelley DS, Baross JA, Cary SC (ed) The Subseafloor Biosphere at mid-Ocean Ridges. Geophys Monogr Ser 144, AGU, Washington, DC

Gamo T, Okamura K, Charlou JL, Urabe T, Auzende JM, Ishibashi J, Shitashima K, Chiba H, Shipboard Scientific Party of the ManusFlux Cruise (1997) Acidic and sulfate-rich hydrothermal fluids from the Manus back-arc basin, Papua New Guinea. Geology 25:139-142

Gamo T, Ishibashi J, Tsunogai U, Okamura K, Chiba H (2006) Unique geochemistry of submarine hydrothermal fluids from arc-back-arc settings of the western Pacific. In: Christie DM, Fisher CR, Lee SM, Givens S (ed) Back-arc Spreading Systems-Geological, Biological, Chemical, and Physical Interactions. Geophys Monogr Ser 166, AGU, Washington, DC

German CR, Von Damm KL (2004) Hydrothermal processes. In: Turekian KK, Holland HD (ed) The Treatise on Geochemistry Chapter 6.07. Elsevier, New York

German CR, Bowen A, Coleman ML, Honig DL, Huber JA, Jakuba MV, Kinsey JC, Kurz MD, Leroy S, McDermott JM, de Lepinay BM, Nakamura K, Seewald JS, Smith JL, Sylva SP, Van Dover CL, Whitcomb LL, Yoerger DR (2010) Diverse styles of submarine venting on the ultraslow spreading Mid-Cayman Rise. Proc Natl Acad Sci U S A 107:14020-14025

Hajash A, Chandler GW (1981) An experimental investigation of high-temperature interactions between seawater and rhyolite andesite basalt and peridotite. Contrib Mineral Petrol 78:240-254

Hannington M, Jamieson J, Monecke T, Petersen S, Beaulieu S (2011) The abundance of seafloor massive sulfide deposits. Geology 39:1155-1158

Helgeson HC, Kirkham DH, Flowers GC (1981) Theoretical prediction of the thermodynamic behavior of aqueous electrolytes at high pressures and temperatures IV: calculation of activity coefficients osmotic coefficients and relative partial molal properties to $600^{\circ} \mathrm{C}$ and $5 \mathrm{~kb}$. Am J Sci 281:1249-1516

Holler T, Widde F, Knittel K, Amann R, Kellermann MY, Hinrichs KU, Teske A, Boetius A, Wegener G (2011) Thermophilic anaerobic oxidation of methane by marine microbial consortia. ISME J 5:1946-1956

Huber JA, Holden JF (2008) Modeling the impact of diffuse vent microorganisms along mid-ocean ridges and flanks. In: Lowell RP, Seewald JS, Metaxas A, Perfit MR (ed) Magma to Microbe: Modeling Hydrothermal Processes at Oceanic Spreading Centers. Geophys Monogr Ser 178, AGU, Washington, DC

Huber JA, Morrison HG, Huse SM, Neal PR, Sogin ML, Mark Welch DB (2009) Effect of PCR amplicon size on assessments of clone library microbial diversity and community structure. Environ Microbiol 11:1292-1302

Humphris SE, Zierenberg RA, Mullineaux LS, Thomson RE (1995) Seafloor Hydrothermal Systems_-Physical, Chemical, Biological, and Geological Interactions. Geophys Monogr Ser 91, AGU, Washington, DC

Inagaki F, Kuypers MMM, Tsunogai U, Ishibashi J, Nakamura K, Treude T, Ohkubo S, Nakaseama M, Gena K, Chiba H, Hirayama H, Nunoura T, Takai K, Jorgensen BB, Horikoshi K, Boetius A (2006) Microbial community in a sediment-hosted $\mathrm{CO}_{2}$ lake of the southern Okinawa Trough hydrothermal. Proc Natl Acad Sci U S A 103:14164-14169

Ishibashi J, Urabe T (1995) Hydrothermal activity related to arc-backarc magmatism in the western Pacific. In: Taylor B (ed) Backarc Basins: Tectonics and Magmatism. Plenum, New York

Janecky DR, Seyfried WE, Jr (1986) Hydrothermal serpentinization of peridotite within the oceanic crust: experimental investigations of mineralogy and major element chemistry. Geochim Cosmochim Acta 50:1357-1378

Jannasch HW, Mottl MJ (1985) Geomicrobiology of deep-sea hydrothermal vents. Science 229:717-725

Karl DM (1995) Ecology of free-living hydrothermal vent microbial communities. In: Karl DM (ed) Microbiology of Deep-sea Hydrothermal Vents. CRC, Boca Raton

Kawagucci S, Chiba C, Ishibashi J, Yamanaka T, Toki T, Muramatsu Y, Ueno Y, Makabe A, Inoue K, Yoshida N, Nakagawa S, Nunoura T, Takai K, Takahata N, Sano Y, Narita T, Teranishi G, Obata H, Gamo T (2011) Hydrothermal fluid geochemistry at the Iheya North field in the mid-Okinawa trough: implication for origin of methane in subseafloor fluid circulation systems. Gechem J 45:109-124

Kawagucci S, Ueno Y, Takai K, Toki T, ito M, Inoue K, Makabe A, Yoshida N, Muramatsu Y, Takahata N, Sano Y, Narita T, Teranishi G, Obata H, Nakagawa S, Nunoura T, Gamo T (2013) Geochemical origin of hydrothermal fluid methane in sediment-associated fluids and its relevance to the geographical distribution of whole hydrothermal circulation. Chem Geol 339:213-225

Kawahata H, Nohara M, Ishizuka H, Hasebe S, Chiba H (2001) Sr isotope geochemistry and hydrothermal alteration of the Oman ophiolite. J Geophys Res 106:11083-11099
Kelley DS, Karson JA, Blackman DK, Fruh-Green GL, Butterfield DA, Lilley MD, Oison EJ, Schrenk MO, Roe KK, Lebon GT, Rivizzigno P, the AT3-60 Shipboard Party (2001) An off-axis hydrothermal vent field discovered near the Mid-Atlantic Ridge at 30N. Nature 412:145-149

Kelley DS, Baross JA, Delaney JR (2002) Volcanoes fluids and life at mid-ocean ridge spreading centers. Annu Rev Earth Planet Sci 30:385-491

Kelley DS, Karson JA, Fruh-Green GL, Yoerger DR, Shank TM, Butterfield DA, Hayes JM, Schrenk MO, Oison EJ, Proskurowski G, Jakuba M, Bradley A, Larson B, Ludwig K, Glickson D, Buckman K, Bradley AS, Brazelton WJ, Roe K, Elend MJ, Delacour A, Bernasconi SM, Lilley MD, Baross JA, Summons RE, Sylva SP (2005) A serpentinite-hosted ecosystem: the lost city hydrothermal field. Science 307:1428-1434

Lam P, Cowen JP, Popp BN, Jones RD (2008) Microbial ammonia oxidation and enhanced nitrogen cycling in the Endeavour hydrothermal plume. Geochim Cosmochim Acta 72:2268-2286

Leat PT, Larter RD (2003) Intra-oceanic subduction systems introduction. In: Larter RD, Leat PT (ed) Intra-Oceanic Subduction Systems Tectonic and Magmatic Processes. Geol Soc London Spec Publ, London

Lesniewski RA, Jain S, Anantharaman K, Schloss PD, Dick GJ (2012) The metatranscriptome of a deep-sea hydrothermal plume is dominated by water column methanotrophs and lithotrophs. ISME J 6:2257-2268

Lilley MD, Butterfield DA, Olson EJ, Lupton JE, Macko SA, McDuff RE (1993) Anomalous $\mathrm{CH}_{4}$ and $\mathrm{NH}_{4}$-concentrations at an unsedimented mid-ocean-ridge hydrothermal system. Nature 364:45-47

Lilley MD, Butterfield DA, Lupton JE, Olson EJ (2003) Magmatic events can produce rapid changes in hydrothermal vent chemistry. Nature 422:878-881

Lupton J, Butterfield D, Lilley M, Evans L, Nakamura K, Chadwick W Jr, Resing J, Embley R, Olson E, Proskurowski G, Baker E, de Ronde C, Roe K, Greene R, Lebon $G$, Young $C$ (2006) Submarine venting of liquid carbon dioxide on a Mariana Arc volcano. Geochem Geophys Geosys 7:Q08007. doi:10.1029/ 2005GC001152

Lupton J, Lilley M, Butterfield D, Evans L, Embley R, Massoth G, Christenson B, Nakamura K, Schmidt M (2008) Venting of a separate $\mathrm{CO}_{2}$-rich gas phase from submarine arc volcanoes: examples from the Mariana and TongaKermadec arcs. J Geophys Res 113:B08S12. doi:10.1029/2007JB005467

Luther GW, Gartman A, Yucel M, Madison AS, Moore RS, Nees HA, Nuzzio DB, Sen A, Lutz RA, Shank TM, Fisher CR (2012) Chemistry temperature and faunal distributions at diffuse flow hydrothermal vents comparisons of two geologically distinct ridge systems. Oceanography 25:234-245

Mandernack KW, Tebo BM (1993) Manganese scavenging and oxidation at hydrothermal vents and in vent plumes. Geochim Cosmochim Acta 57:3907-3923

McCollom TM (2007) Geochemical constraints on sources of metabolic energy for chemolithoautotrophy in ultramafic-hosted deep-sea hydrothermal systems. Astrobiology 7:933-950

McCollom TM, Shock EL (1997) Geochemical constraints on chemolithoautotrophic metabolism by microorganisms in deep-sea hydrothermal systems. Geochim Cosmochim Acta 61:4375-4391

McCollom TM, Shock EL (1998) Fluid-rock interactions in the lower oceanic crust: thermodynamic models of hydrothermal alteration. J Geophys Res 103:547-575

McCollom TM, Seewald JS (2001) A reassessment of the potential for reduction of dissolved $\mathrm{CO}_{2}$ to hydrocarbons during serpentinization of olivine. Geochim Cosmochim Acta 65:3769-3778

Merkel AY, Huberb JA, Chernyha NA, Bonch-Osmolovskayaa EA, Lebedinskya AV (2013) Detection of putatively thermophilic anaerobic methanotrophs in diffuse hydrothermal vent fluids. Appl Environ Microbiol 79:915-923

Mottl MJ (1983) Hydrothermal processes at seafloor spreading centers: application of basalt-seawater experimental results. In: Rona PA, Bostrom K, Laubier L, Smith KL (ed) Hydrothermal Processes at Seafloor Spreading Centers. Plenum, New York

Mottl MJ, Holland HD (1978) Chemical exchange during hydrothermal alteration of basalt by seawater-l: experimental results for major and minor components of seawater. Geochim Cosmochim Acta 42:1103-1115

Nakagawa S, Takai K (2008) Deep-sea vent chemoautotrophs diversity biochemistry and ecological significance. FEMS Microbiol Ecol 65:1-14

Nakagawa S, Takai K, Inagaki F, Hirayama H, Nunoura T, Horikoshi K, Sako Y (2005a) Distribution phylogenetic diversity and physiological characteristics of epsilon-proteobacteria in a deep-sea hydrothermal field. Environ Microbiol 7:1619-1632

Nakagawa S, Takai K, Inagaki F, Chiba H, Ishibashi J, Kataoka S, Hirayama H, Nunoura T, Horikoshi K, Sako Y (2005b) Variability in microbial community and venting chemistry in a sediment-hosted backarc hydrothermal system: impacts of subseafloor phase-separation. FEMS Microbiol Ecol 54:141-155 
Nakamura K, Kato Y, Tamaki K, Ishii T (2007) Geochemistry of hydrothermally altered basaltic rocks from the Southwest Indian Ridge near the Rodriguez Triple Junction. Mar Geol 239:125-141

Nakamura K, Morishita T, Bach W, Klein F, Hara K, Okino K, Takai K, Kumagai H (2009) Serpentinized troctolites exposed near the Kairei hydrothermal field Central Indian Ridge: insights into the origin of the Kairei hydrothermal fluid supporting a unique microbial ecosystem. Earth Planet Sci Lett 280:128-136

Nealson KH, Inagaki F, Takai K (2005) Hydrogen-driven subsurface lithoautotrophic microbial ecosystems (SLiMEs): do they exist and why should we care? TRENDS Microbiol 13:405-410

Nunoura T, Takai K (2009) Comparison of microbial communities associated with phase-separation-induced hydrothermal fluids at the Yonaguni Knoll IV hydrothermal field, the Southern Okinawa Trough. FEMS Microbiol Ecol 67:351-370

Nunoura T, Oida H, Nakaseama M, Kosaka A, Ohkubo SB, Kikuchi T, Kazama H, Hosoi-Tanabe S, Nakamura K, Kinoshita M, Hirayama H, Inagaki F, Tsunogai U, Ishibashi J, Takai K (2010) Archaeal diversity and distribution along thermal and geochemical gradients in hydrothermal sediments at the Yonaguni Knoll IV hydrothermal field in the Southern Okinawa Trough. Appl Environ Microbiol 76:1198-1211

Perner M, Kuever J, Seifert R, Pape T, Koschinsky A, Schmidt K, Strauss H, Imhoff JF (2007) The influence of ultramafic rocks on microbial communities at the Logatchev hydrothermal field, located $15^{\circ} \mathrm{N}$ on the Mid-Atlantic Ridge. FEMS Microbiol Ecol 61:97-109

Perner M, Petersen JM, Zielinski F, Gennerich H-H, Seifert R (2010) Geochemical constraints on the diversity and activity of $\mathrm{H}_{2}$-oxidizing microorganisms in diffuse hydrothermal fluids from a basalt- and an ultramafic-hosted vent. FEMS Microbiol Ecol 74:55-71

Perner M, Hentscher M, Rychlik N, Seifert R, Strauss H, Bach W (2011) Driving forces behind the biotope structures in the low-temperature venting at $5^{\circ} \mathrm{S}$ and $9^{\circ} \mathrm{S}$ MAR. Environ Microbiol Repts 3:727-737

Perner M, Gonella G, Hourdez S, Böhnke S, Kurtz S, Girguis P (2013a) In-situ chemistry and microbial community compositions in five deep-sea hydrothermal fluid samples from Irina II in the Logatchev field. Environ Microbiol 15:1551-1560

Perner M, Hansen M, Seifert R, Strauss H, Koschinsky A, Petersen S (2013b) Linking geology fluid chemistry and microbial activity of basalt- and ultramafichosted deep-sea hydrothermal vent environments. Geobiology 11:340-355

Petersen JM, Zielinski FU, Pape T, Seifert R, Moraru C, Amann R, Hourdez S, Girguis PR, Wankel SD, Barbe V, Pellerier E, Fink D, Borowski C, Bach W, Dubiller N (2011) Hydrogen is an energy source for hydrothermal vent symbioses. Nature 476:176-180

Reysenbach A-L, Shock E (2002) Merging genomes with geochemistry in hydrothermal ecosystems. Science 296:1077-1082

Reed MH (1983) Seawater-basalt reaction and the origin of greenstones and related ore deposits. Econ Geol 78:466-485

Roussel EG, Konn C, Charlou JL, Donval JP, Fouquet Y, Querellou J, Prieur D, Bonavita MAC (2011) Comparison of microbial communities associated with three Atlantic ultramafic hydrothermal systems. FEMS Microbiol Ecol 77:647-665

Saccocia J, Seyfried WE, Jr (1990) Talc-quartz equilibria and the stability of magnesium chloride complexes in $\mathrm{NaCl}-\mathrm{MgCl}_{2}$ solutions at 300,350 , and $400^{\circ} \mathrm{C} 500$ bars. Geochim Cosmochim Acta 54:3283-3295

Saccocia PJ, Ding K, Berndt ME, Seewald JS, Seyfried WE, Jr (1994) Experimental and theoretical perspectives on crustal alteration at mid-ocean ridges. In: Lentz D (ed) Alteration and Alteration Processes Associated With ore-Forming Systems. Geological Association of Canada Short Course Notes, Québec

Sakai H, Gamo T, Kim ES, Tsutsumi M, Tanaka T, Ishibashi J, Wakita H, Yamano M, Oomori T (1990) Venting of carbon dioxide-rich fluid and hydrate formation in mid-Okinawa Trough backarc basin. Science 248:1093-1096

Sanders JG, Beinart RA, Stewart FJ, Delong EF, Girguis PR (2013) Metatranscriptomics reveal differences in in situ energy and nitrogen metabolism among hydrothermal vent snail symbionts. ISME J 7:1556-1567

Schmincke H-U (2004) Volcanism. Springer, Berlin

Schouten S, Wakeham SG, Hopmans EC, Damsté JSS (2003) Biogeochemical evidence that thermophilic Archaea mediate the anaerobic oxidation of methane. Appl Environ Microbiol 69:1680-1686

Seyfried WE Jr (1987) Experimental and theoretical constraints on hydrothermal alteration processes at mid-ocean ridges. Annu Rev Earth Planet Sci 5:317-335

Seyfried WE Jr, Mottl MJ (1982) Hydrothermal alterations of basalt by seawater under seawater-dominated conditions. Geochim Cosmochim Acta 46:985-1002
Seyfried WE Jr, Ding K (1995) Phase equilibria in subseafloor hydrotherma systems: a review of the role of redox temperature $\mathrm{pH}$ and dissolved $\mathrm{Cl}$ on the chemistry of hot spring fluids at mid-ocean ridges. In: Humphris S, Mullineaux L, Zierenberg R, Thomson R (ed) Seafloor Hydrothermal Systems: Physical, Chemical, Biological, and Geological Interactions. Geophys Monogr Ser, vol. 91, AGU, Washington, DC, pp 248-273

Seyfried WE Jr, Berndt ME, Seewald JS (1988) Hydrothermal alteration processes at mid-ocean ridges - constraints from diabase alteration experiments, hot spring fluids and composition of the oceanic crust. Can Mineral 26:787-804

Seyfried WE Jr, Ding K, Berndt ME (1991) Phase equilibria constraints on the chemistry of hot spring fluids at mid-ocean ridges. Geochim Cosmochim Acta 55:3559-3580

Seyfried WE Jr, Ding K, Berndt ME, Chen X (1999) Experimental and theoretical controls on the composition of mid-ocean ridge hydrothermal fluids. Rev Econ Geol 8:181-200

Shock EL (1992) Chemical environments of submarine hydrothermal systems. Origin Life Evol Biosphere 22:67-107

Shock EL, Holland ME (2004) Geochemical energy sources that support the subsurface biosphere. In: Wilcock WSD, DeLong EF, Kelley DS, Baross JA, Cary SC (ed) The Subseafloor Biosphere at mid-Ocean Ridges. Geophys Monogr Ser vol. 144, AGU, Washington, DC, pp 153-165

Shock EL, Helgeson HC, Sverjensky DA (1989) Calculation of the thermodynamic and transport properties of aqueous species at high pressures and temperatures: standard partial molal properties of inorganic neutral species. Geochim Cosmochim Acta 53:2157-2183

Spiess FN, Macdonald KC, Atwater T, Ballard R, Carranza A, Cordoba D, Cox C, Diaz Garcia VM, Francheteau J, Guerrero J, Hawkins J, Haymon R, Hessler R, Juteau T, Kastner M, Larson R, Luyendyk B, Macdougall JD, Miller S, Normark W, Orcutt J, Rangin C (1980) East Pacific Rise: Hot springs and Geophysical experiments. Science 207:1421-1433

Sunamura M, Higashi Y, Miyako C, Ishibashi J, Maruyama A (2004) Two bacteria phylotypes are predominant in the Suiyo seamount hydrothermal plume. Appl Environ Microbiol 70:1190-1198

Suzuki Y, Kojima S, Sasaki T, Suzuki M, Utsumi T, Watanabe H, Urakawa H, Tsuchida S, Nunoura T, Hirayama H, Takai K, Nealson KH, Horikoshi K (2006) Host-symbiont relationships in hydrothermal vent gastropods of the genus Alviniconcha from the Southwest Pacific. Appl Environ Microbiol 72:1388-1393

Takai K, Horikoshi K (1999) Genetic diversity of Archaea in deep-sea hydrothermal vent environments. Genetics 152:1285-1297

Takai K, Nakamura K (2010) Compositional physiological and metabolic variability in microbial communities associated with geochemically diverse deep-sea hydrothermal vent fluids. In: Barton LL, Mandl M, Loy A (ed) Geomicrobiology: Molecular and Environmental Perspective. Springer, Berlin, pp 251-283

Takai K, Nakamura K (2011) Archaeal diversity and community development in deep-sea hydrothermal vents. Curr Opin Microbiol 14:282-291

Takai K, Komatsu T, Inagaki F, Horikoshi K (2001) Distribution of archaea in a black smoker chimney structure. Appl Environ Microbiol 67:3618-3629

Takai K, Gamo T, Tsunogai U, Nakayama N, Hirayama H, Nealson KH, Horikoshi K (2004a) Geochemical and microbiological evidence for a hydrogen-based, hyperthermophilic subsurface lithoautotrophic microbial ecosystem (HyperSLiME) beneath an active deep-sea hydrothermal field. Extremophiles 8:269-282

Takai K, Oida H, Suzuki Y, Hirayama H, Nakagawa S, Nunoura T, Inagaki F, Nealson KH, Horikoshi K (2004b) Spatial distribution of marine Crenarchaeota group I in the vicinity of deep-sea hydrothermal systems. Appl Environ Microbiol 70:2404-2413

Takai K, Nakamura K, Suzuki K, Inagaki F, Nealson KH, Kumagai H (2006a) Ultramafics-Hydrothermalism-Hydrogenesis-Hyperslime (UltraH ${ }^{3}$ ) linkage: a key insight into early microbial ecosystem in the archean deep-sea hydrothermal systems. Paleontol Res 10:269-282

Takai K, Nakagawa S, Reysenbach AL, Hoek J (2006b) Microbial ecology of midocean ridges and back-arc basins. In: Christie DM, Fisher CR, Lee SM, Givens S (ed) Back-arc Spreading Systems: Geological, Biological, Chemical, and Physical Interactions. Geophys Monogr Ser vol 166, AGU, Washington, DC, pp 185-213

Takai K, Nunoura T, Ishibashi J, Lupton J, Suzuki R, Hamasaki H, Ueno Y, Kawagucci S, Gamo T, Suzuki Y, Hirayama H, Horikoshi K (2008) Variability in the microbial communities and hydrothermal fluid chemistry at the newly discovered Mariner hydrothermal field southern Lau Basin. J Geophys Res 113:G02031. doi:0201001029/02007JG000636

Tivey MK (2004) Environmental conditions within active seafloor vent structures: sensitivity to vent fluid composition and fluid flow. In: Wilcock WS, DeLong EF, Kelley DS, Baross JA, Craig Cary S (ed) Subseafloor Biosphere at mid-Ocean Ridges. Geophys Monogr Ser vol. 144, AGU, Washington, DC, pp 137-152 
Tivey MK (2007) Generation of seafloor hydrothermal vent fluids and associated mineral deposits. Oceanography 20:50-65

Tivey MK, Becker E, Beinart R, Fisher CR, Girguis PR, Langmuir CH, Michael PJ, Reysenbach AL (2012) Links from mantle to microbe at the Lau Integrated Study Site: insights from a back-arc spreading center. Oceanography 25:62-77

Van Dover CL (2000) The Ecology of Deep-sea Hydrothermal Vents. Princeton University Press, New Jersey

Von Damm KL (1988) Systematics of and postulated controls on submarine hydrothermal solution chemistry. J Geophys Res 93:4551-4561

Von Damm KL (1990) Seafloor hydrothermal activity: black smoker chemistry and chimneys. Ann Rev Earth Planet Sci 18:173-204

Von Damm KL (1995) Controls on the chemistry and temporal variability of seafloor hydrothermal fluids. In: Humphris SE, Zierenberg RA, Mullineaux LS, Thomson RE (ed) Seafloor Hydrothermal Systems: Physical, Chemical, Biological, and Geological Interactions. Geophys Monogr Ser vol 91, AGU, Washington, DC, pp 222-247

Von Damm KL (2000) Chemistry of hydrothermal vent fluids from $9^{\circ}-10^{\circ} \mathrm{N}$, East Pacific Rise: "Time zero" the immediate posteruptive period. J Geophys Res 105:11203-11222

Wallace PJ, Edmonds M (2011) The sulfur budget in magmas: evidence from melt inclusions submarine glasses and volcanic gas emissions. Rev Mineral Geochem 73:215-246

Wang F, Zhou H, Meng J, Peng X, Jiang L, Sun P, Zhang C, Van Nostrand JDV, Deng Y, He Z, Wu L, Zhou J, Xiao X (2009) GeoChip-based analysis of metabolic diversity of microbial communities at the Juan de Fuca Ridge hydrothermal vent. Proc Natl Acad Sci U S A 106:4840-4845

Wankel SD, Joye SB, Samarkin VA, Shah SR, Friederich G, Melas-Kyriazi J, Girguis PR (2010) New constraints on methane fluxes and rates of anaerobic methane oxidation in a Gulf of Mexico brine pool via in situ mass spectrometry. Deep-Sea Res II 57:2022-2029

Watsuji T, Nakagawa S, Tsuchida S, Toki T, Hirota A, Tsunogai U, Takai K (2010) Diversity and function of epibiotic microbial communities on the galatheid crab Shinkaia crosnieri. Microbes Environ 25:288-294

Watsuji T, Nishizawa M, Morono Y, Hirayama H, Kawagucci S, Takahata N, Sano Y, Takai K (2012) Cell-specific thioautotrophic productivity of epsilonproteobacterial epibionts associated with Shinkaia crosnieri. PLoS One 7:e46282. doi:10.1371/journal.pone.0046282

Watsuji T, Yamamoto A, Takaki Y, Ueda K, Kawagucci S, Takai K (2014) Diversity and methane oxidation of active epibiotic methanotrophs on live Shinkaia crosnieri. ISME J. doi:10.1038/ismej.2013.226

Wetzel LR, Shock EL (2000) Distinguishing ultra-mafic from basalt-hosted submarine hydrothermal systems by comparing calculated vent fluid compositions. J Geophys Res 105:8319-8340

Wilcock WW, DeLong E, Kelley DS, Baross JA, Cary SC (2004) The Subseafloor Biosphere at mid-Ocean Ridges. Geophys Monogr Ser vol. 144, AGU, Washington, DC

doi:10.1186/2197-4284-1-5

Cite this article as: Nakamura and Takai: Theoretical constraints of physical and chemical properties of hydrothermal fluids on variations in chemolithotrophic microbial communities in seafloor hydrothermal systems. Progress in Earth and Planetary Science 2014 1:5.

\section{Submit your manuscript to a SpringerOpen ${ }^{\circ}$ journal and benefit from:}

- Convenient online submission

- Rigorous peer review

- Immediate publication on acceptance

- Open access: articles freely available online

- High visibility within the field

- Retaining the copyright to your article

Submit your next manuscript at $\gg$ springeropen.com 